\title{
Kripto Paraların Yatırım Amaçlı Kullanımı: Riskler ve Getiriler ${ }^{\mathrm{a}}$
}

\author{
Semra Öncü ${ }^{b}$ Doğuş Ektik ${ }^{c, d}$
}

\section{Özet}

Kripto paraların portföy riskine ve getirisine etkilerininin ölçüldüğü ve yorumlandığı bu çalışmada; kripto paraların yatırımcılar için faydalı portföy aracı olarak kullanılabilirliği araştırılmış, aktif para birimi olarak kullanımlarına yönelik incelemelerde bulunulmuş ve çeşitli portföy içerikleri ile performans ölçümleri yapılmıştır. Araştırmada, evren ve örneklem olarak 2018 yıl sonu itibariyle kripto para piyasalarında en yüksek işlem hacmine sahip üç kripto para, ülkemizde en yüksek işlem hacmine sahip üç döviz kuru, ülkemizde yaygın olarak yatırım araçları içerisinde yer alan üç endeks ve işlem hacmi en yüksek üç emtia incelenmiştir. Yapılan analizler ve literatür değerlendirmesi neticesinde kripto paraların yüksek oynaklığa sahip olması ve henüz varoluş amacına uygun olarak değişim aracı niteliğinden çok yatırım aracı olarak kullanılması kripto paralar için ulaşılan olumsuz sonuçlar olarak gözlenmiştir. Fakat portföy içeriğine katıldığında gösterdikleri zıt korelasyon ile risk - getiri değerlendirmesinde portföyü olumlu etkilediği ve performansları ile yüksek getiri elde edilebileceği anlaşılmıştır.
Anahtar Kelimeler

Kripto Para

Modern Portföy Teorisi

Performans Ölçümü

Optimum Portföy

Makale Hakkında

Geliş Tarihi: 28.10.2021

Kabul Tarihi: 15.12.2021

Doi: 10.18026/cbayarsos.1015799

\section{Cryptocurrencies for Investment Use: Risks and Returns}

\begin{abstract}
In this study, in which the effects of cryptocurrencies on portfolio risk and return are measured and interpreted; The usability of cryptocurrencies as a useful portfolio tool for investors was researched, investigations were made for their use as active currency and performance measurements were made with various portfolio contents. In this context, as the universe and sample, the three cryptocurrencies with the highest transaction volume in the crypto money markets as of the end of 2018, the three exchange rates with the highest transaction volume in our country. As a result of the analysis and literature review, the high volatility of crypto coins and their use as an investment tool rather than an exchange tool in accordance with their purpose of existence are observed as negative consequences for crypto currencies. However, it is understood that the opposite correlation they show when included in the portfolio content positively affects the portfolio in risk-return assessment and that high returns can be obtained with their performances.
\end{abstract}

Keywords

Cryptocurrency

Modern Portfolio Theory

Performance Measurement

Optimum Portfolio

\begin{tabular}{|r|} 
About Article \\
\hline Received: 28.10 .2021 \\
Accepted: 15.12 .2021 \\
\hline
\end{tabular}

Doi: 10.18026/cbayarsos.1015799

\footnotetext{
a Bu çalışma Doğuş Ektik tarafından hazırlanan “Kripto Paraların Yatırım Amaçlı Kullanımı: Riskler ve Getiriler” (Danışman: Prof. Dr. Semra Öncü) adlı doktora tezinden üretilmiştir.

b Prof. Dr., Manisa Celal Bayar Üniversitesi İ.İ.B.F. İşletme Bölümü, semra.oncu@cbu.edu.tr, ORCID: 0000-0003-2315-5438

c İletişim Yazarı: dogusektik@aydin.edu.tr

d Dr. Öğr. Üyesi, İstanbul Aydın Üniversitesi İ.İB.F. Muhasebe ve Finans Yönetimi Bölümü, dogusektik@aydin.edu.tr, ORCID: 0000-0001-7095-6364
} 


\section{Giriş}

Bilişim teknolojisi son yıllarda hızlı bir gelişim ile hayatın her alanına girerken bu arada para üzerinde de etkisini göstermeye başlamıştır. Para geçmişten günümüze pek çok değişim sürecinden geçmiştir. Başlangıçta takas sistemi ile başlayan ödeşmeler, çeşitli değerli madenlerin para olarak kullanılmasına, sonrasında temsili paralara, ardından kağıt paraya ve bir kayıt şeklinde tutulan banka parasına ulaşması yetmeyip, teknolojik gelişim ile uyumlu olacak şekilde bu değişim elektronik paraların ve beraberinde kripto paraların ortaya çıkmasına kadar uzanmıştır.

Kasım 2017 itibariyle günlük işlem hacmi 3 milyar doları geçen kripto paraların, yaşadığı evrim sürecinde hem gelişiminin hem de muhtemel etkilerinin analiz edilmesi tüm ülkeler ve bireyler için finansal gelişim açısından önem arz etmektedir. Günümüzde yüksek oynaklığa sahip olması ve hukuki açıdan kurallara tabii olmaması nedeniyle daha çok yatırım amacı olarak kullanılan kripto paraların yatırımcı portföyüne etkileri çok önemlidir.

Kripto paraların portföy riskine ve getirisine etkilerini ölçmek ve yorumlamak bu çalışmanın ana amacıdır. Ayrıca altyapı olarak kullanılan blockchain hakkında araştırmalar yapmak, aktif para birimi olarak kullanımlarına yönelik incelemelerde bulunmak diğer amaçlar arasındadır. Doğrudan devlet müdahalesine tabi tutulamayan sanal para birimleri olan kripto paralar reel ekonomiye doğrudan etki etme gücüne sahiptir. İşlem masrafları yok denecek kadar az olan ve kısa sürede çok yüksek işlem hacimlerine ulaşan kripto paraların bu işlem düzeyine ulaşma sebebi yatırımcıların yüksek oynaklık düzeylerini fırsata çevirme çabalarıdır. Kripto paraların portföy riski ve getirisine etkilerini bilimsel olarak incelemek yatırımcların karar alma süreçlerinde doğru kararlar vermelerine yardımcı olmak açısından önemlidir.

Ana amacı kripto paraların portföy riskine ve getirisine etkilerini incelemek olan bu çalışma; para, kripto para, blockchain üzerine araştırmalar yapılarak modern portföy teorisine yönelik literatür taraması ile portföy teorisi üzerinde birleştirilmiştir. BIST100 endeksi baz alınarak ve çeşitli kripto paralar ve çeşitli yatırım araçları eklenerek getiri, standart sapma, kovaryans ve korelasyon katsayıları hesaplanacak, yatırım performansları değerlendirilmiş, optimum performansı veren bileşenler bulunarak yorumlanmıştır.

\section{Literatür Araştırması}

Yatırım yöneticileri ve bireyler, yatırımlarını yönlendirirken her zaman daha fazla değer oluşturmak için yeni yöntem ve strateji arayışında bulunurlar. Bu arayış Klasik Portföy Yönetiminin uygulandığı zamanlarda da olduğu gibi şimdi de devam etmektedir. Klasik Portföy Yönetiminin uygulandığı dönemlerdeki arayışlar yatırımcıları Markowitz sayesinde Modern Portföy Yönetimine yönlendirmiştir.

Yatırımclar, Modern Portföy Yönetimi anlayışı ile ve optimum portföy hesaplamaları ile yatırımlarının verimliliğini artırmayı başarmışlardır. Ayrıca portföy performans ölçüm modelleri ile de yatırımlarının performansını her an somut veriler ile değerlendirebilmişlerdir. Yatırımların verimliliğini artırmak ve ölçmek üzere literatürde çokça bilimsel araştırma yapılmıştır. Kripto paraların Modern Portföy Teorisi ile yatırımlarda kullanıldığı, portföy performanslarının değerlendirildiği ve sonuçlarının analiz edildiği çalışmalar ve içerikleri aşağıda özetlenmiştir.

Bocconi Students Investment Club tarafından 7 Mayıs 2017 yılında hazırlanan "A Markowitz Walk Down Crypto-land: Modern Assets for Modern Portfolios" isimli çalışmada Modern 
Portföy Teorisinin matematiksel çerçevesini sıradışı bir varlık grubu olan kripto paralara uygulamanın amaçlandı̆̆ı belirtilmiştir. (Bocconi Students Investment Club, 2017). Markowitz'in Portföy Teorisi'ni uygulayarak, portföyün genel oynaklı̆̆ını azaltmak için varlıkların ortak değişkenliğinden (yani kovaryans) faydalanmak amaçlanmıştır. Günlük fiyatların kullanıldığı çalışmada yanlızca iki yıldan fazla süredir piyasa verileri olan ve araştırma tarihindeki değeri 100 milyon doları aşan kripto paraları kıstas almışlardır. Araştırmanın hazırlandığı tarihlerde kriterlere uyan altı kripto para birimi olduğu anlaşılmıştır. Sonuç olarak beklentiler ile tutarlı bir şekilde kripto paralar ile çeşitlendirmenin portföyü optimize ettiği görülmüştür.

Yonghyeon Nam tarafından Ritsumeikan Asia Pacific University'de 2017 yılında hazırlanan "A New Opportunity of Bitcoin for Improving Portfolio Efficiency in Japan" isimli yüksek lisans tezinde "Bitcoin portföyün verimliliğini artırabilir mi?" ve "Hangi portföy optimizasyon stratejisi Bitcoin'in dahil edildiği portföy için en iyi risk-getiri profilini yaratabilir?" sorularına yanıt aranmıştır. Sharpe Oranı, Sortino Oranı, VaR ve CVaR yöntemleri uygulanan 2010-2016 yılları arasındaki 74 aylık Bitcoin verileri ve para birimi, hisse senedi, gayrimenkul verileri gibi çeşitli portföy unsurları kullanılmıştır (Nam, 2017). Araştırma sonuçlarında portföye Bitcoin eklenmesi ile portföyün verimliliğinde önemli artış elde edildiği anlaşılmıştır.

Thomas Ankenbrand ve Denis Bieri 2018 yılında "Assessment of Cryptocurrencies as an Asset Class by Their Characteristics" isimli, Investment Management and Financial Innovations dergisinde yayınlanan çalışmalarında kripto para birimlerinin varlık olarak kabul görmeleri durumunda yatırım aracı olarak çeşitlendirmenin önemine dikkat çekmişlerdir. Çalışmada öncelikle kripto para birimlerinin özellikleri incelenmiş, ardından sayısal yöntemler ile oluşturulan kripto para ve diğer varlık portföylerinin analizi yapılmıştır (Ankenbrand \& Bieri, 2018). Kripto para birimlerinin yüksek oynaklık içerdiği görülmüş ve geleneksel varlıklar ile düşük korelasyona sahip olmaları sebebiyle yatırım çeşitlendirmek için iyi bir seçenek olarak görülürken, ticaret hacimlerinin düşük olmasını ise dezavantaj olarak belirtmişlerdir.

R.W.J. Hazewinkel, hazırladığı 2017 yılında yayınlanan “Bitcoin: a Diversifier, Hedge or Safe Haven" isimli Bitcoin'in risk yönetimi özellikleri ile ilgili araştırmada dokuz varlık içeren bir ABD portföyü ve Bitcoin ile çeşitlendirmenin, riskten korunma ve güvenli varlık özelliklerini araştırmayı amaçlamıştır. Regresyon sonuçları, Bitcoinin bir çeşitlendirici görevi üstlenebileceğini göstermektedir. Bitcoin değerindeki yüksek oynaklığa rağmen, Bitcoin'in düşük korelasyonu ABD portföyü için çeşitlilik avantajları sağlamaktadır. Araştırma sonuçlarına göre Black-Litterman modeliyle yapılan ek testler, portföyün oransal olarak az miktarda Bitcoin içermesinin ABD portföyü için faydalı olduğunu göstermektedir. Elde edilen bu bulgu Modern Portföy Teorisi sonuçlarına paraleldir (Hazewinkel, 2017).

Amaury ve Ward (2018) tarafından Bitcoin'i bir finansal varlık olarak analiz etmek olarak amaçlanan "Bitcoin as a Financial Asset: Impact of Bitcoin on a Well-Diversified European Portfolio" isimli tezde Bitcoin'in 2014 - 2017 arasındaki üç yılını kapsayan veriler ile, iyi çeşitlendirilmiş Avrupa hisse senetlerinin bulunduğu portföyün bir arada kullanılmasının faydaları analiz edilmiştir. Çeşitlendirmedeki risk değişimini incelemek için Markowitz'in Modern Portföy Teorisi kullanılan bu araştırmada Bitcoin; eşit ağırlıklı bir portföye, yalnızca uzun vadeli bir portföye ve kısa satıma olanak sağlayan bir portföye eklenerek gruplandırılmıştır. Araştırma sonuçlarında, iyi çeşitlendirilmiş bir Avrupa portföyünün yaklaşık \% 2'sine Bitcoin eklenmesinin hem kısa satış hem de uzun satış portföyündeki Sharpe oranını önemli ölçüde arttırdığı gözlemlenmiştir (Martens de Wilmars \& Vondeling, 2019). 
Sjoerd Klabbers'in "Bitcoin as an Investment Asset: The Added Value of Bitcoin in a Global Market Portfolio" adlı yüksek lisans tezinde bir yatırım varlığı olarak Bitcoin'in çeşitlilik avantajları sağlayıp sağlamadığı, Bitcoin'in hedge veya güvenli liman özelliklerine sahip olup olmadığı araştırılmıştır. Bu araştırmada, Bitcoin gibi çok değişken bir varlık için önemli bir unsur olarak görülen tahmin riski konusunu ele almak için Monte-Carlo Simülasyonu ile ortalama varyans risk-getiri çerçevesi kullanılmıştır. Araştırmanın bulguları tutarlı bir şekilde Bitcoinin portföy içerisinde \% 5'e kadar ağırlı̆ga sahip olması durumunda etkili bir çeşitlendirici olduğunu göstermektedir (Klabbers, 2017). Araştırma sonuçlarına göre Bitcoin, küresel çapta piyasa portföyü için herhangi bir riskten korunma veya güvenli liman özelliği göstermemektedir. Bitcoin portföy içerisinde yüksek getiri imkanı sağlasa da, varlığın kendine özgü risk özellikleri ile birlikte var olduğu sonuçlarına ulaşılmıştır. "Bitcoin May Be a Portfolio Diversifier but There Are Still Risks" adiyla Prableen Bajpai tarafindan sunulan ve www.thestreet.com web sitesinde yayınlanan makalede Modern Portföy Teorisi ile Bitcoin'in etkileri birlikte değerlendirilmiştir. Makalede Bitcoin'in yapısal risklerinden bahsedilerek yatırım için şüpheli olduğu sonucuna varılmıştır (Prableen, 2019).

International Review of Financial Analysis dergisinde Gorbet vd. tarafından hazırlanan (Corbet, Lucey, Andrew, \& Yarovaya, 2019) "Cryptocurrencies as a Financial Asset: a Systematic Analysis" isimli makalede 2009 yılında bir finansal varlık olarak geliştirilmesinden bu yana kripto para birimleri piyasasıyla ilişkilendirilen ana konulara dayanan ampirik literatürün sistematik bir incelemesi sunulmuştur. Araştırma sonuçlarına göre düzenleyici gözetimi, var olan yasadışı kullanım potansiyeli, az gelişmiş bir değişim sistemi içindeki anonimliği ve siber suçluluğun büyümesinden etkilenen altyapısal ihlaller arasında var olan risklerden her biri kripto para birimlerinin güvenilir bir yatırım, varlık sınıfı ve değer meşruiyeti olarak algılanmasına engel oluşturmaktadır.

Finance Research Letters dergisinde Brauneis ve Mestel'in 2018 yılında yayınladığ "Cryptocurrency Portfolios in a Mean-Variance Framework" çalışmalarında kripto para portföylerinin risk-getiri verilerini değerlendirmek için Markowitz Ortalama-Varyans riskgetiri çerçevesini uygulamışlardır. 1/1/2015 - 12/31/2017 tarihleri arasında en fazla kullanılan en büyük 500 kripto para günlük verilerinin kullanıldığ 1 çalışmada işlem maliyetini hesaba katan bir örneklem analizinde, düşük riskli kripto para birimlerinin yatırım fırsatlarını zenginleştirdiğini tespit etmişlerdir (Brauneis \& Mestel, 2019).

Trimborn, Li ve Härdle'ın 2017 yılında Berlin'de hazırladıkları çalışmada Markowitz Ortalama-Varyans çerçevesinde likidite sınırlı risk-getiri optimizasyonu (LIBRO) yaklaşımınını kullanmışlardır. Araştırma sonuçlarında, kripto para birimlerinin portföy içerisine olumlu değer kattığı ve optimizasyon yaklaşımının bir portföyün getirisini artırabildiği, oynaklık riskini azalttığı görülmektedir (Trimborn, Li, \& Hardle, 2017).

Economics Letters dergisinde Platanakis, Sutcliffe ve Urquhart tarafından 2018 yılında hazırlanan "Optimal vs Naïve Diversification in Cryptocurrencies" adlı makalede dört popüler kripto para birimi portföyündeki optimal çeşitlendirmenin performansını inceleyerek kripto para birimleri hakkındaki literatüre katkıda bulunmuşlardır (Platanakis, Sutcliffe, \& Urquhart, 2018). Haftalık verileri kullanan araştırmacılar klasik çeşitlendirme ile optimum çeşitlendirme arasında farkın çok az olduğunu sonucuna ulaşmışlardır.

Weiyi Liu, 2018 yılında Finance Research Letters dergisinde yayınlanan "Portfolio Diversification Across Cryptocurrencies" adlı çalışmada (Liu, 2018) işlem hacmi en yüksek on 
kripto para biriminin ampirik verilerini kullanarak, kripto para portföyündeki çeşitliliğin yatırımlardaki verimliliğini incelemiştir. Çalışmada farklı kripto para birimleri arasında portföy çeşitliliğinin yatırım sonuçlarını önemli ölçüde artırabileceği görülmüştür.

2018 y1lında Platanakis ve Urquhart tarafından hazırlanan ve Economics Letters dergisinde yayınlanan "Portfolio Management With Cryptocurrencies: The Role of Estimation Risk" isimli çalışmada (Platanakis \& Urquhart, 2019) kripto para portföyündeki tahmin hatalarını kontrol eden varyansa dayalı kısıtlamalar ile portföy performanslarını karşılaştırarak portföy yönetimi ve tahmin riskleri incelemiştir. Çalışmada Markowitz Portföy Çeşitlendirmesini ve gelişmiş Black-Litterman modeli karşılaştırılmıştır. Çalışmada varyansa dayalı kısıtlamalara sahip gelişmiş Black-Litterman modelinin, örneklem dişı riske uyarlanmış getirileri arttırdığ ve daha düşük portföy riski sağladığı görülmüştür.

Andrianto ve Diputra 2017 yılında Journal of Finance and Accounting dergisinde yayınlanan çalışmalarında, kripto paraların iyi oluşturulmuş portföyler üzerindeki etkilerini incelemişlerdir (Andrianto \& Diputra, 2017). Kullandıkları varlıklar yabancı para, emtia, hisse senedi ve borsa yatırım fonlarıdır. Kullandıkları kripto paralar Bitcoin, Ripple ve Litecoin'dir. Çalışmada Modern Portföy Teorisi yaklaşımı kullanarak bir yatırım portföyü oluşturulmuştur. Çalışma sonuçları kripto para özellikli portföyün etkinliği iki şekilde artırdığını göstermektedir. Birincisi, standart sapmayı en aza indirgemek, ikincisi ise yatırımcıların seçebileceği daha fazla varlık seçeneği yaratmak. Analize göre kripto paraların optimum yatırım düzeyi, yatırımcının risk toleransına bağlı olarak \% 5 ile \% 20 arasındadır.

International Review of Financial Analysis dergisinde yayınlanan ve 2018 y1lında Kajtazi ve Moro tarafından hazırlanan "The Role of Bitcoin in Well Diversified Portfolios: a Comparative Global Study" adlı çalışmada (Kajtazi \& Moro, 2019), ortalama CVaR yaklaşımına dayanarak, Bitcoin ilavesinin optimal bir portföye etkilerini araştırmışlardır. Ayrıca araştırmada Bitcoin'in $\mathrm{ABD}$, Avrupa ve Çin varlık portföylerindeki rolü de araştırılmıştır. Portföylerin Bitcoin içeren ve içermeyen performanslarını her senaryo için karşılaştırmak için tekrar test yapılmış, sonuçlarda Bitcoin ekleyerek portföy performansının arttırıldığı; ancak bu durumun getirilerdeki dalgalanmanın azalmasından değil, getiri artışından kaynaklanmakta olduğu öğrenilmiştir. Ek olarak, bu sonucun 2013'teki Bitcoin değerinde yaşanan sıçrayış ile bağlantılı olduğu düşünülmektedir.

2019 yılında St Petersburg University Journal of Economic Studies dergisinde yayınlanan "Cryptocurrency as an Investment Instrument in a Modern Financial Market" adlı çalışmada onbeş kripto para arasındaki korelasyon Modern Portföy Yönetimi yaklaşımı ile incelenmiş ve kripto varlıkların kısa dönemde çok riskli oldukları sonucuna ulaşılmıştır (Saksonova \& Kuzmina-Merlino, 2019). “The Impact of Cryptocurrency on the Efficient Frontier of Emerging Markets" adlı çalışmada ise, Bitcoin içeren portföylerin etkin sınır içerisinde yer aldığ gözlemlenmiştir. Çalışmada, ayrıca portföy performans ölçümlerinde Sharpe oranından da yararlanılmıştır (Ćosić \& Časni, 2019).

2020 yılında Dumlupınar Üniversitesi Sosyal Bilimler Dergisi'nde yayınlanan “Kripto Paralar ve Portföy Çeşitlendirmesi" adlı çalışmada kripto paraların portföy çeşitlendirmesi amacıyla kullanılıp kullanılamayacağı araştırılmıştır (Gül, 2020). 7 Ağustos 2015 - 23 Ocak 2020 tarih aralığındaki günlük verileri kullanarak, hisse senetleri, emtialar, döviz kurları ve yatırım fonlarından meydana gelen portföyler farklı stratejilerle oluşturulmuştur. Oluşturan portföylere kripto paralar (Bitcoin, Ethereum, Ripple) ilave edilerek, portföy 
performanslarındaki değişiklikler izlenmiştir. Çalışma sonuçlarında kripto paralar ile diğer varlıkların arasındaki korelasyonların çoğunlukla negatif olduğu, kripto paraların eklendiği portföylerin genel olarak daha yüksek getirilere ve Sharpe Oranlarına sahip olduğu ayrıca daha düşük riske katlanıldığı görülmüştür.

\section{Para, Elektronik Para ve Kripto Para Kavramları}

Yerleşik hayata geçen tüm insanlar adı daha sonra "para" olarak anılacak değişik şeyler üretmeye, kullanmaya ve geliştirmeye başlamıştır. Söz konusu süreç tüm toplumlarda aynı şekilde, ancak farklı zamanlarda görülmüştür. Nitekim dünyanın eski medeniyetlerini Sümer, Mısır, Minos (Girit), Çin, Maya ve And olmak üzere 6 grup altında toplayan Toynbee, çalışmasında sadece İnkaların, metal para kullanmadan yüksek bir medeniyet seviyesine geçebildiğini ifade etmiştir.

Geçmişten günümüze uzunca bir süre değişimlerde ve ticarette madeni para hüküm sürmüş, 17. yüzyıldan sonra ise kağıt para yaygınlaşmaya başlamıştır. 1400'lü yıllarda Avrupa'da metal paralar kullanılsa da, matbaanın bulunması para arzının genişlemesini sağlayan kâğıt paranın kullanılabilmesi için gerekli ön koşul olan teknolojik yeteneğin Avrupa'da elde edilmesine yol açmıştır. Ancak bu yeteneğe rağmen Avrupa'da kâğıt paranın kullanılması için tam 200 yıl beklenmiştir. Çin'in (günümüz dünyasına benzer bir şekilde) para basmanın enflasyona yol açacağı bilincine tam olarak varamaması ile oluşan hiper enflasyon sonucu Çin'de kâğıt paraların kullanımına son verilmesi Avrupa'ya kötü bir kâğıt para tecrübesi olarak yansımıştır. Bu tecrübe Avrupa'da kâğıt para kullanımını geciktirmiş olsa da Avrupa'da gelişen ticaret ile artan para talebini lojistik açıdan karşılayabilecek yeni altın madenlerinin bulunması kâğıt paraya geçişi engelleyen diğer önemli bir faktördür.

Leonardo Da Vinci'nin icadı olan para damgalama makinesinin 1645 yılında Paris Darphanesi tarafından kullanılması ve hızlı bir şekilde standart madeni para üretimi sağlanabilmiş olması (Davies, 2002) ihtiyaç duyulan para talebini hızlı bir şekilde karşılayabilmiş olsa da ekonomik genişleme ile paraya olan talebin artması, kâğıt paraya göre nispeten güvenilir olan madeni paraların kullanılmasındaki zorlukları göz önüne sermiştir.

Bu dönemde kâğıt para ise gerek taşıma gerekse üretim maliyeti açısından oldukça avantajlı olması nedenleriyle ön plana çıkmış, para sisteminin kurumsallaşmasına neden olan kâğıt para ile ilgili düşünceler gelişmeye başlamıştır. 1705 yılında John Law, Money and Trade Considered With a Proposal for Supplying the Nation with Money adlı eserinde kâğıt paranın (Law, 1705);
a. Dolaşım kolaylığı,
b. Her yerde aynı değerde olması,
c. Bir yerde saklanması,
d. Kayıp olmadan bölünmesi,
e. Sahteciliği önlemesi gibi nedenlerden ötürü gümüş paraya göre daha avantajlı olduğunu savunmuştur.

Matbaanın yanı sıra, ekonomik faaliyetlerin sistematik bir şekilde kayıt altına alınmasını sağlayan "çift kayıt" sisteminin 1494 yılında İtalya'da yayınlanması paranın gelişmesinde önemli olan diğer bir gelişmedir. Bernstein, çalışmasında muhasebe sistemlerinde çı̆̆ır açan bu buluşun 300 yıl sonra icat edilecek buhar makinesiyle kıyaslanabilecek kadar önemli 
ekonomik sonuçları olduğunu belirtmektedir (Bernstein, 2008). Kapitalizmin doğumu ve Werner Sombart'in 1922 yılında yayınlanan “Der Modern Capitalismus (Modern Kapitalizm)" eserinde belirttiği gibi kapitalizmin gelişimine doğrudan etkisi olan "çift kayıt sistemi" (Charnes, Cooper, \& Ijiri, 1963), kaydi paraya geçişte oldukça önemli bir dönemeçtir.

Dünya tarihinde, en çok kullanılan muhasebe kayıt yöntemlerinden biri olan çift taraflı kayıt yöntemi ticaretin gelişimine ivme kazandırmada etkili olmuştur. Çift taraflı kayıt sisteminden önce ticari işlemler sınırlı hesaplara kayıt ediliyordu. Kayıtlama esnasında muhasebe ile ilgili bilgilerin tamamı değil belirli bölümleri kayıt altına alınıyordu (Örten, Kurt, \& Torun, 2011). Böyle bir sistemde, en önemli sorun yatırımcıların özkaynak değişimini inceleme seçeneğinin bulunmamasıydı. Büyük Alman şair ve düşünürü Goethe' nin “insan dimağının en mükemmel icatlarından biri” olarak ifade ettiği çift taraflı kayıt tekniği (Ryan, 2014), işletme hesaplarının birbirleriyle ilişkili ve düzenli bir şekilde kayıt altına alınmasına olanak sağlamasıyla sermaye ekonomisinin gelişmesinde önemli rol oynamıştır.

Öte yandan para kavramının değişimine etki eden diğer unsur olan bankacilığın kökeni ise ilk çağlara kadar uzanmaktadır. Bankacılık da o dönemde din ile birlikte yer almıştır. Rahiplerin güvenilir kimse olarak görülüp borç verme, ipotek, kefalet gibi bankacılık işlemlerinde rol aldıkları bilinmektedir (Tarlan, 1986). Sümer ve Babillerden başlayıp günümüze kadar gelen bu sistem 13. Yüzyılda Avrupa'da temel kurallarına kavuşmuş, asıl gelişimini çift taraflı kayıt yönteminin de etkisi ile 15. Yüzyıldan sonra gerçekleştirmiştir. Reform ve Rönesans hareketleri de bankacılığın bu yüzyılda gelişimine etki eden çok önemli faktörlerdir. 17. Yüzyıl başlarından itibaren ise bugünkü anlamda bankalar kurulmuştur (Tezer \& Çolak, 1999).

Tarih boyunca hiçbir uluslararası sistemde paranın karşıllğı statik kalmamıştır. Sistemler günümüze değin değişiklik göstermiştir. Tarihsel süreç içerisinde düzenli olarak kullanılan ilk para sistemi 1880'lerden 1914 yılına kadar süren ve tarihte "klasik altın standardı" olarak anılan dönemdir. Çoğu kez "altın dönem" olarak nitelendirilen bu dönemde ülkeler hızlı bir büyüme ve fiyat istikrarı yaşamışlar ve dünya ticareti büyük bir gelişme göstermiştir. Sabit döviz kurlarında ödemeler bilançosu oldukça iyi dengeye sahip olmuştur. Bu dönem mal, emek, ve sermaye için, göreli olarak serbest ticaret dönemi olmuştur (Mumcu, 2007). Bankacılık sistemi bu süreçte gelişmiş ve modern ekonomik sistemin çevresinde yer alan paranın devletler tarafından kontrol edilebilmesi amaciyla yetkili mercii olarak merkez bankaları kurulmuştur.

1816' da İngiltere, 1879' da da ABD Altın'1 resmi değer ölçüsü olarak belirlemiştir. Bu sistemde ulusal para birimi belli bir altın miktarı ile tanımlanmaktaydı ve basılacak her banknotun altın rezervinde bir karşılığı olması gerekiyordu (Cooper, Dornbusch, \& Hall, 1982). Kâğıt paranın uzun bir süre merkez bankalarının rezervindeki altına endekslenmesi Birinci Dünya Savaşı'na kadar devam etmiştir.

Bankacılık sektörünün büyümesi ile para, merkez bankaları tarafından belirlenen temsili özelliğinden çıkarak kaydi bir statüye bürünmüştür. 1944'te ABD dolarının altına endekslenmesi ile ülkelerin döviz fiyatlarını altına değil dolara endekslemesi kararlaştırılmış ve dolar rezerv para olarak kabul edilmiştir. Bretton Woods olarak adlandırılan bu sistem ile doların altına sabitlenmesi uygulamasının 1971 yılında ABD tarafından kaldırılmasıyla dünyada altın standardı sistemi tamamen sona ermiştir. Böylece ABD Merkez Bankası (FED) istediği miktarda doları piyasaya aktarabilecek bir yetkiye sahip olmuştur. Bretton Woods' dan 
sonra para önemli bir politika aracı olarak küresel ölçekte ön plana çıkarken, ABD'nin siyasal ve ekonomik egemenlik düzeyini de artırmıştır (Mumcu, 2007).

Graeber, geleneksel olarak takas işlemleri ön plana çıkarılsa da paranın temelinde borç alacak ilişkisi üzerine kurulan bir güven olgusunun bulunduğunu ifade etmiştir. Paranın herhangi bir metalden ziyade borçlu-alacaklı arasındaki inanç ve güven ilişkisi şeklinde görülmesi gerektiğini; paranın, özünde bir nesnenin değerinden çok diğer insanlara duyulan güvenin ölçüsünü gösterdiğini söylemiştir (Graeber, 2015). Araştırmada, paranın karşıllk kavramında yaşanan değişiklikler başlığı içerisinde özetlenen süreçte de görüleceği üzere Bretton Woods uygulamasının 1971 yılında kaldırılması ile kaydi nitelik öne çıkmış ve bu temeli bir emtiaya veya herhangi bir varlığa bağlı kalmayan para sadece güven olgusuna tutunur hale gelmiştir. Günümüzde bu kaydi değer ve güven taşıyan para kavramı elle tutulur fiziki niteliğinin geriye kalan son unsuru olan banknot halininim elektronik ortama aktarılması ile güven olgusu daha hissedilir olmuştur.

\section{Elektronik Para}

Türkiye'deki yasal düzenlemelerde 2013 yılında kabul edilen 6493 sayılı Ödeme ve Menkul Kıymet Mutabakat Sistemleri, Ödeme Hizmetleri ve Elektronik Para Kuruluşları Hakkında Kanun'un (Resmi Gazete, 2013). 3. maddesinde elektronik paranın tanımı "elektronik para ihraç eden kuruluş tarafından kabul edilen fon karşılığ 1 ihraç edilen, elektronik olarak saklanan, bu Kanun'da tanımlanan ödeme işlemlerini gerçekleştirmek için kullanılan ve elektronik para ihraç eden kuruluş dışındaki gerçek ve tüzel kişiler tarafından da ödeme aracı olarak kabul edilen parasal değer" olarak yer almıştır. Görüldüğü üzere elektronik para hakkında yapılan tanımlarda ortak nokta elektronik ortamda saklanabilme özelliği ve parayı çıkaran kuruluş dışındaki kişilerce de kabul edilmesidir.

Bank of International Settlements, Ödemeler ve Piyasa Altyapıları Komitesi (CPMI) (BIS CPMI, 2015) para türlerinin sınıflandırırken geniş algıda elektronik parayı iki alt başlığa ayırmıştır;

a. Resmi Olarak Tanımlanmış Elektronik Para,

b. Dijital Para.

Dijital para da iki alt başlığa ayrılmıştır;

a. Merkez Bankası Parası Karşılığında Üretilen Dijital Para,

b. Merkez Bankası Parasından Bağımsız Olarak Özel Sektör Tarafından Üretilen Dijital Para Aynı raporda, değişim mekanizmasında para türleri başlığı altında bazı açıklamalar yapilmıştır:

Fiziksel Varlık-Para: Tarafların fiziki para değişimini yüzyüze-birebir gerçekleştirdiği değişim araci.

Kaydi Para: Bankacılık sisteminde tarafların bir araya gelmesine gerek kalmadan ödeme yapılmasına imkan veren, üçüncü bir tarafın oluşturacağı güven zincirine ihtiyaç duyulan değişim aracı.

Resmi Olarak Tanımlanmış ve Merkez Bankası Parasına Dayalı Elektronik Para: E-para değişim mekanizması ile bire bir banka gibi üçüncü bir tarafa ihtiyaç duyulmadan ya da merkezi ödeme sistemleri aracılığıyla paranın el değiştirmesine izin verilen değişim aracı. 
Özel Olarak Düzenlenen Dijital Para: Merkezi olmayan bir ödeme mekanizması (blokzincir vb.), eş dügümler arası (P2P) elektronik değişim imkanı sağlayan araç (örn. Kripto paralar).

\section{Kripto Para}

Kripto para; şifreli olarak güvenli işlem yapmaya ve ek elektronik para arzı yaratmaya olanak sunan dijital paralardır. Kripto paralar olgu olarak alternatif para birimi yapısı ile var olmuşlardır. Kripto paralar merkezi olmayan yapıdadırlar. Bu yapının kontrolü ilgili işlemler defterlere (Blockchain vb.) veri tabanı tarafından gerçekleştirilmektedir. Dolaşımdaki paranın miktarı ve arzı, hangi şekillerde ve ne zaman dolaşıma sokulacağ ${ }_{1}$ kripto para sisteminin kuruluş aşamasında belirlenmektedir. Bu aynı zamanda para arzının artırılamayacağı anlamını taşımaktadır. Kripto para sisteminde Merkez Bankası gibi bir kontrol mekanizması ya da temel bankacılık işlemlerini yürüten bir kurum ya da kişi bulunmamaktadır.

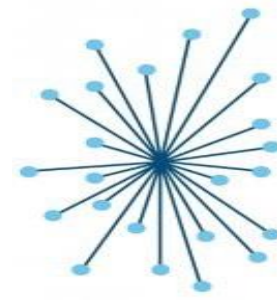

Merkezi Yapı

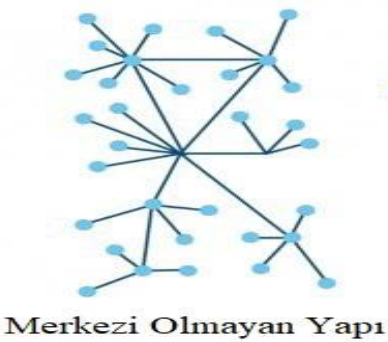

Merkezi Olmayan Yapı

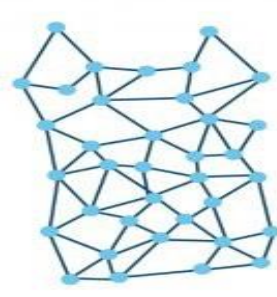

Dağıtık Yapı

Şekil 1. A $\breve{g}$ yapıları

Kaynak: Oğuzhan Taş ve Farzad Kiani."Blok Zinciri Teknolojisine Yapılan Saldırılar Üzerine Bir İnceleme". Bilişim Teknolojileri Dergisi. Cilt 11, Sayı 4, Ocak 2018, s.370.

Şekil 1'de ağ yapılarına ait görseli incelediğimizde merkezi yapının bir noktadan hareket ettiği ve tüm paydaşların merkez ile etkileşimi olduğu görülmektedir. Merkezi olmayan yapıda paydaşların merkez ile bağlantısı kalmadığı ve gruplar halinde etkileşim içerisinde olduğu görülürken, dağıtık yapıda tüm paydaşların birbiri ile etkileşim kurabildiği görülmektedir. Merkezi olmayan yapıların sorumluluğu dağıttığını, dağıtık yapıların ise bir sonraki aşama olarak sorumluluğu eşit paylaştırdığını ifade edebiliriz. Özünde dağıtık yapıyı merkezi olmayan yapı kapsamında değerlendirmek mümkündür. Bitcoin veritabanı olan blockchain, dağıtık özellikte çalışan bir ağ yapısına sahip iken, dağıtık yapıda olmayan fakat merkezi olmayan yapıya sahip kripto paralar da bulunmaktadır.

Kriptoloji, eski bir Yunanca kelime olan kryptos kelimesinden türetilmiştir. Kriptografi de Yunanca granhien sözcüğünden türetilmiş olup verilerin şifrelenmesini ifade etmektedir (Usta \& Doğantekin, 2018). Kriptografi; gizlilik, kimlik denetimi, bütünlük gibi kavramların elde edilebilmesi için çalışan matematiksel yöntemler bütünüdür. Bu yöntem sayesinde bir bilginin çeşitli teknikler kullanılarak istenmeyen taraflarca okunamayacak hale getirilmesi söz konusudur. Kripto paralar kriptografi ile şifrelenmiş sanal paralardır. Kripto paralar bir merkezden diğerine transfer edilebilmektedir. Kripto paraların güvenlikleri şifreleme yöntemleri ile sağlanmaktadır. Kripto paralarda para veya değer transferi yaparken aracı ortadan kalkmaktadır. Geçmişte merkezi olmayan kripto para sistemi çalışmaları çokça gerçekleşmiştir fakat tekrarlı ödeme (mükerrer ödeme) problemi çözülememiştir. Uçtan uca (Peer to Peer) mesaj, transfer ve ödeme ile tekrarlı ödeme problemi çözülmüştür. P2P' de (Peer to Peer) veri tek bir merkezde değildir. Sayısı milyonları bulabilecek makineler üzerinden 
paylaşılmış durumdadır. Bu makinelerin bazılarında verinin tamamı bulunurken bazılarında verinin bir kısmı bulunmaktadır. Kullanıcılar sistemde istedikleri veriyi çektiklerinde aynı zamanda sisteme veri de göndermiş olmaktadırlar. Kripto paralar; mutabakat yaklaşımı, mutabakat yapısı, kripto para üretim aşamasında kullanılan problem, kullanılan özetleme algoritması, platform kapsamındaki diğer hizmet kabiliyetlerinin geliştirilmesi, her yeni blok eklemek için gerekli ortalama süre, blok büyüklügü ve yaratılabilecek kripto para miktarı olarak birbirinden farklı özellikler göstermektedir. Araştırma tarihleri aralığında işlem hacmi en yüksek üç kripto para Bitcoin, Ethereum ve Ripple olarak karşımıza çıkmaktadır.

\section{Bitcoin}

Merkeziyetsiz ilk ve bu ilklik ile en güçlü kripto para olan Bitcoin, 2009 yılında internette ilk kez kullanılmaya başlandığından bu yana kullanıcıları arasında ticareti yapılan deneysel bir varlıktan, dünyada popüler olan ve büyüyen bir ekonomiye dönüşmüştür. Bitcoin'in küresel kullanıcı tabanı giderek çeşitlenirken, işlem gördüğü itibari para birimlerinin sayısı da günden güne artmaktadır. Bitcoin kripto para çalışma sisteminde, hedeflenen alıcı ile işlem miktarının bulunduğu genel anahtarın bir karması ile imzalanarak gerçekleştirilmekte yani kripto para gönderilmektedir. İstenen alıcının genel anahtarının bu karması bir adres olarak bilinmektedir. Tipik olarak bu karma bir standartlaşmış şifre formatındadır. Rakam ve harflerden oluşan örneğin "7E2oetdNuQUqRHPJmcMHHDYoqkyNVsFc7r" benzeri bir dizilime sahiptir. Bitcoin'i almak için bir kullanıcı kendi açık adresini (genel anahtarını) paylaşmaktadır (Quesnelle, 2018).

Birçok talimat kullanıcılar arasındaki çoklu teyitleşme mekanizması ile deftere (block) yazılır. Bitcoinler daha sonra ilgili özel anahtarla yeni bir işlemin gerçekleşmesinde imzalanmak suretiyle kullanılabilmektedir. İşlemler bloklara dahil edilinceye kadar tamamlanmamış sayılırlar. Tamamlanan işlem blok iş kanıtı karması belgesiyle yayınlanan işlemlerin bir derlemesinden ibarettir. Sistem kullanıcıların iyi davranışını teşvik etmek amacıyla geçerli bir iş kanıtı ile birlikte bir bloğun başarılı bir şekilde yayınlanmasını sağlayan kişileri blok ödülü olarak bilinen yeni üretilen coinlerle ödüllendirmektedir. Bitcoin arzı yirmi bir milyon bitcoin ile sınırlandırılmıştır. İş kanıtını çözmeye çalışan kullanıcılar ve yeni blok üretenler "madenciler" olarak bilinirler. Blok ödüle ek olarak, her işlem için madenciye ödenecek bir ücret öngörülebilir. Madenciler, yaptıkları işlemin ücret seviyesine göre bir blokta yer edinmek için ekonomik olarak rekabet etmektedirler.

Her blok bir önceki bloğun bir karmasını içerdiğinden dolayı Bitcoin kurallarına uyan en uzun Blokzinciri ağın mutabakat hali olarak kabul edilir. Bir saldırgan blokları göz ardı etse bile, uygun olan müşteriler her zaman en uzun iş zincirini takip ederek en fazla iş güvenliğini sağlayabilmektedir. Bitcoin'in kısaltması "BTC" ile ifade edilmektedir. Bitcoin'in en küçük birimine "satoshi" denir ve 100 milyon satoshi 1 BTC (1 sathoshi=0,00000001 Bitcoin) olarak hesaplanır. Üretimi ve el değişimi sanal ortamlarda gerçekleştirildiğinden dolayı Bitcoin fiziksel bir para değildir. Bitcoin mekanizmasında iş kanıtına (Proof of Work) dayalı madencilik sürecinde peş peşe karma adı verilen şifrelerin sıralanmasıly oluşturulan bir Blokzinciri bulunur. Sistemdeki zorluk seviyesine göre (hash) oluşturulan şifrelerin bazıları birkaç adet sıfır rakamı ile başlar ve bu durumun oluştuğu şifreye "altın karma" (gold hash) denir. Altın karmayı ortaya çıkaran (problemi çözerek bloğu zincire ekleyen) Bitcoin madencisi, yeni yaratılan Bitcoinler ile ödüllendirilmektedir (Aksoy, 2018).

\section{Ethereum}


Ethereum, sistem olarak; blokzincir modeli kullanılarak kripto para birimlerinin ve ak1llı sözleşme protokollerinin kullanılabilmesini sağlayan ve bu sistemi merkezi olmayan uygulamaları oluşturmak ve dağıtmak için kullanan bir ağ alt yapısıdır. Kripto para birimi olarak Ethereum (ETH) ise bu ekosistemin para birimidir, kısaca Ether olarak tarif edilir. Bu ekosistemin geliştiricisi Vitalik Buterin, Ethereum veri yapısının Bitcoin gibi blokzincir teknolojisiyle çalıştığını ancak Bitcoin'den farklı yönleri bulunduğunu ve "Turing Complete" adı verilen kendine ait programlama diline sahip olduğunu belirtmektedir (Buterin, 2013).

Ethereum ağında iki tip hesap bulunmaktadır; ilki kullanıc kontrolündeki Ether bakiyelerini gösteren dış hesaplardır. Diğeri ise kendi kodu tarafından kontrol edilen akıllı kontratlardır. $\mathrm{Bu}$ sistemde akıllı kontratlar ve Ethereum arasında işlemler yapılabilmesine olanak sağlayan geniş bir uygulama yelpazesi sunulmaktadır (Dhillon, Metcalf, \& Hooper, 2017). Borç kayıtlarının veya vadeli işlem sözleşmesi gibi taahhütlerin depolanmasını veya henüz icat edilmemiş birçok şeyin saklanmasını mümkün hale getirmektedir. Bu sebeple Ethereum ağı, yazıldığ 1 zaman itibariyle test ağı kurulmasına ve çalışmasına rağmen halen akıllı kontratlar ile inşa edilmektedir.

Ethereum'daki sözleşmeler, sözleşmeyi tutan hesaba bir işlem gönderildiğinde, blok zincirindeki dügümler tarafından yürütülen kod parçalarıdır. Sözleşmeyi tutan hesap, sözleşme tarafından kullanılabilecek bir dâhili bellek durumunu korumaktadır. Bir sözleşme ile; miktar, gönderen adresi ve diğer yardımcı alanlar gibi, onu etkinleştiren işlemden çeşitli detaylara da erişilmektedir. Bir sözleşmenin uygulanması, diğer sözleşmeleri etkinleştirebilen yeni işlemlerin oluşturulmasına neden olabilmektedir. Sözleşmeler tarafından gönderilen işlemler ilk oluşturucusuna kazanç sağlayabilmektedir (Franco, 2014). Bu yönü ile Ethereum ağı çok geniş kapsamlı bir işlem mekanizması olarak görülmekte ve bu ağın para birimi Ether de bu işlemlerde kullanılabilen iktisadi değer olarak nitelendirilmektedir.

\section{Ripple}

Bitcoin'den önce, 2004 yılında Ryan Fugger ile British Columbia Vancouver'de başlayan proje global ve merkezi olmayan mutabakat sistemini kullanan bir havale ağ tanımlanmaktadır. Ripple ekosistemi, farklı para birimleri arasında alışveriş yapan ödemeler için dağınık, açık kaynaklı bir ağ protokolü iken, bu ekosistemin para birimi de Ripple (XRP) olarak adlandırılmaktadır. Ripple ağı, merkezi olmayan bir döviz bürosu görevi görür ve Ripple hesapları hakkında bilgi saklayan genel muhasebe defterine dayanır. Bu ağda bankalar gibi finansal kuruluşlar, likidite sağlayıcı taraflar bulunur. Ağın yönetimi, bankalar ve piyasa yapıcılar dâhil olmak üzere bağımsız meslektaşlar tarafından sağlanmaktadır (Hileman \& Rauchs, 2017). Ripple ekosisteminde yüz milyar Ripple bulunmaktadır ve yapılan işlemler uzlaşı ile doğrulanmaktadır. İşlemler yayınlanır yayınlanmaz Ripple defterine uygulanmamakta, bir işlem için salt çoğunluk sağlandığında işlem onaylanmaktadır. Ripple defteri; hesap ayarlarını, defter numarasını, işlemleri ve zaman damgasını saklamaktadır. Defterler tarih sırasına göre kriptografik bağlarla bağlanmakta ve her işlem sahibi tarafından imzalanmaktadır. İşlemler madencilik tarafından değil, uzlaşı ile doğrulanmaktadır. İşlemler geri alınamaz ve saniyeler içinde doğrulanabilmektedir. Doğrulama esnasında bağlantı noktaları için tüm blok zincirini indirmeleri gerekmemektedir. Böylece işlemler saniyeler içinde gerçekleşebilmektedir (Yakupoğlu, 2016). Ripple, genellikle bankaların farklılaşmış ürün ve hizmetlerle gelirlerini arttırarak yeni müşteriler kazanabilmeye olanak sağlamak ve gerçek zamanlı, sınır ötesi para transferlerinde kullanımıyla verimlilikleri arttırmak, uluslararası ödemeler için işletme maliyetlerini düşürmek amacı ile tercih edilmektedir. 
Mevcut yapıda finansal servislere ulaşımın oldukça pahalı olması, merkezi yapıda aracılar arasındaki ödeme sürecindeki mesaj ve ödemelerin bağımsız olması, işlem süreçlerinde sık hatalar yapılmasının fon transferinde belirsizliklere neden olması, Uluslararası ödemelerin haftalar alabilmesi, bankaların hazine işlemleri, ödeme işlemleri, likidite gibi işlemlerinde önemli maliyetlerinin olması bankacılık sisteminin dezavantajlarını oluşturmaktadır. Ripple ekosistemi ve Ripple (XRP) bu sorunlara çözüm önermektedir (Ripple, 2016). Ripple'ı diğer kripto paralardan ayıran en önemli özelliği madenciliğin olmaması ve bir şirket kimliği nedeniyle merkezsiz olma görüşünü benimsememesidir.

\section{Portföy Seçimi ve Modern Portföy Yönetimi}

Yatırımcların amacı risk faktörünü dikkate alarak toplam getiriyi maksimize etmektir. Riski en aza indirme amacı ile portföy kavramı ortaya çıkmıştır. Bir varlık yerine portföy yatırımı yapmak daha az riskli olabilir çünkü bir yatırım aracının düşük performansı, başka bir yatırım aracının iyi performansıyla kolayca dengelenebilir (Küçükbay \& Araz, 2016). Portföy seçimi ve yönetiminde iki temel portföy yaklaşımı bulunmaktadır. Bunlardan ilki “geleneksel portföy yönetimi" olarak adlandırılan, basit çeşitlendirme esasına dayanan ve bilimsel temeller yerine portföy yöneticisinin yorumlarını temel alan yaklaşımdır. Geleneksel portföy yönetimi temel olarak portföy içerisindeki varlık sayısının öznel görüş ile sayıca çeşitlendirilmesi ile riskin düşürülmesi esasına dayanır. Geleneksel portföy yönetimi, uygulama kolaylığı sebebiyle hâlâ sıklıkla kullanılmaktadır. İkincisi Harry Markowitz ile 1952 yılında başlayan "modern portföy yönetimi" olarak adlandırılan matematiksel ve istatistiksel temellere dayanan yaklaşımdır (Korkmaz, Aydın, \& Sayılgan, 2013). Bilimsel bir dayanak ile hareket etmesi, varlıkların tarihi getirileri, riskleri, birbirleri ile olan nicel ilişkisi (kovaryans) gibi verileri dikkate alması geleneksel portföy yönetiminden farklı temel noktalarını oluşturmaktadır.

Portföy; farklı yatırım araçlarından oluşan, çoğunlukla hisse senedi, tahviller gibi varlıklardan ve türev ürünlerden oluşan, belirli bir kişi ya grubun elinde olan finansal varlıklar grubu olarak tanımlanır (Ceylan \& Korkmaz, 1998). Geleneksel Portföy Yaklaşımı'nın temeli, yatırımcının yatırım sepetine dahil ettiği varlık sayısını arttırarak, çeşitlendirme aracılığıyla portföy riskini azaltmaktır. Bu yaklaşıma göre portföye dâhil edilen varlık arttıkça portföyün riski azalmaktadır. Aksi durumda yani varlık sayısı az olduğunda ise toplam riskin yüksek olacağı varsayılmaktadır. Şekil 2' de menkul kıymet sayısı arttıkça sistematik olmayan riskin azaldığı dolayısı ile portföy riskinin de azaldığı görülmektedir. Geleneksel Portföy Yaklaşımı'na göre, portföyde yer alan yatırım araçları arttırılarak etkin bir çeşitlendirmenin gerçekleştirilmiş olduğu kabul edilirken, yatırım araçları arasındaki ilişkiler göz ardı edilmektedir. Bu varsayım, Geleneksel Portföy Yaklaşımı'nın en zayıf yönünü oluşturmaktadır. Piyasalarda hiç bir varlığın, diğer varlıklar ile etkileşim içinde olmadığını söylemek mümkün değildir. Portföyü oluşturan varlıklar arasında hiçbir etkileşim olmadığ durumda, Geleneksel Portföy Yaklaşımı verimli bir yönetim yaklaşımı olarak kabul edilebilir ve bu yaklaşıma göre oluşturulan portföylerin sistematik olmayan riski azaltılarak, sistematik risk düzeyine kadar indirilebilir (Tuna, 2011). 


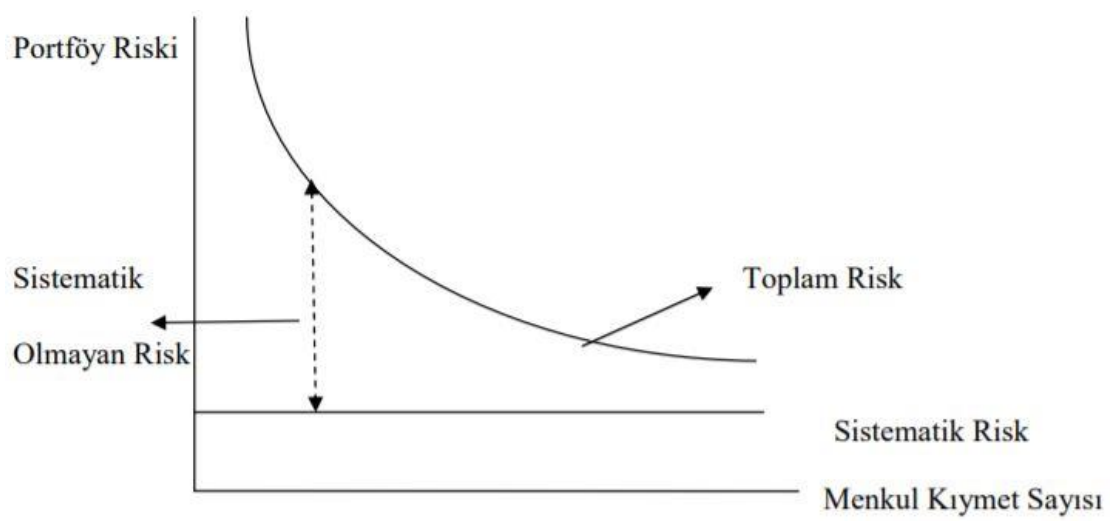

Şekil 2. Geleneksel teoride risk eğrisi

Kaynak: Alexander, G. J., W. P. Sharpe ve J. V. Bailey (1993), Fundamentals of Investments, Prentice Hall, New Jersey.

20. yüzyılın ortalarına kadar devam eden klasik portföy yönetim anlayışı ile portföy yöneticileri ve yatırımcılar, portföyü oluşturan menkul kıymetler arasındaki nicel ilişkileri dikkate almadan sadece portföydeki yatırım araçlarının çeşit ve sayısını artırarak portföy riskini düşürmeyi hedeflemişlerdir (Akmut, 1989). Bu dönemde, portföyü oluşturan yatırım araçlarının çeşitlendirme yapılsa bile korelasyon içerdiği için sorun yarattığ gözlemlenmiştir.

Aynı dönemde, finansal piyasalarda yaşanan gelişmeler dünya ekonomisini ve işletmeleri etkilemekle birlikte bu gelişmeleri yakından izleyen bilim insanlarının ve akademisyenlerin de ilgi odağ 1 olmuştur. 1952 yılında Modern Portföy Teorisinin kurucusu kabul edilen Harry Markowitz, "Portfolio Selection" başlıklı çalışmasında ilk defa portföyü oluşturan yatırım araçları arasındaki korelasyonu portföy seçiminde etki unsuru olarak değerlendirmiştir (Markowitz, 1952). Markowitz, portföyü oluşturan finansal varlıkların getirileri arasındaki ilişkileri inceleyerek birebir pozitif ilişki içinde olmayan yatırım araçlarının portföye eklenerek hedeflenen getirinin risk azaltılarak elde edilebileceğini göstermiştir. Markowitz, çalışmalarında Modern Portföy Teorisini bilime kazandırarak varsayımlarını açıklamıştır.

Bu portföy yönetim anlayışında yatırımcıların amaç fayda fonksiyonunu maksimize etmek klasik anlayış ile benzerlik göstererek temel hedef olmaktadır. Farklılaştıran ise yatırımcıların portföylerini hedefledikleri getiri ve katlanacakları risk olgularına göre oluşturduğunu varsaymasıdır. Bu sebeple yatırımcılar, aynı risk düzeyindeki portföylerden getirisi en yüksek olanı yada aynı getiriyi en az risk ile veren portföyü tercih etmelidir. Bu varsayımları yatırımcıların portföye alacakları yatırım araçları ve piyasa hakkındaki bilgilere maliyetsiz ulaştığını, tüm yatırımcıların portföylerine alacakları her bir yatırım aracının aynı verisine sahip olduğunu kabul ederek ele almaktadır (Markowitz, 1952).

Modern portföy teorisine göre; oluşturulan portföy ile aynı risk düzeyinde başka hiçbir portföy daha yüksek beklenen getiri, ya da aynı beklenen getiri düzeyinde daha düşük risk sağlamıorsa söz konusu portföy etkin portföy olarak kabul edilir (Reilly \& Brown, 2011). Markowitz, modern portföy teorisi ile geleneksel portföy teorisi yaklaşımına görece yatırımcıya fayda sağlayacak üç önemli sonuca ulaşmıştır. Portföy riskinin portföy içindeki her bir yatırım aracının riskinden düşük olabileceği ve şartlara bağlı olarak sistematik olmayan risk toplamının sıfıra yaklaşabileceği varsayılmıştır. Ayrıca, yatırımcı aynı risk düzeyinde en iyi getiriyi sağlayan portföyü ya da aynı getiriyi daha az risk ile sağlayan portföyü tercih etmektedir. Bu tercihleri oluşturan portföy kümelerinin oluşturacağı eğriye etkin sınır eğrisi 
denilmektedir. Diğer önemli sonuç ise, matematiksel ve istatistiksel temele dayanan Markowitz' in geliştirdiği ortalama-varyans modelinin çok fonksiyonlu programlama metodu ile elde edilebileceğidir. Bu sayede portföy kümeleri oluşturulabilir ve doğru etkin sınır bilinebilir (Ceylan \& Korkmaz, 1998). Portföy kümelerinin korelasyon ilişkisi gözetilerek hesaplanmasının önemi ve bu hesaplamalarda kullanılan ortalama varyans modelinin önemi ile Markowitz modelinin adı Ortalama Varyans Modeli olarak da anılmaktadır.

\section{Optimal Portföy Seçimi}

Markowitz' in geliştirdiği Ortalama-Varyans Optimizasyon Modeli, yatırım araçları arasından seçim yapılarak, hedeflenen getiri düzeyinde en düşük riske sahip ya da kabul edilebilir bir risk düzeyinde en yüksek getiriye sahip portföyün oluşturulmasını amaçlar ve portföy seçiminde yaygın olarak kullanılmaktadır. Modele göre bir yatırım aracının hedeflenen getirisi geçmiş verilerden yola çıkarak tahmin edilebilir. Bu tahminin gerçekleşmeme olasılığ (risk) ise finansal varlığın beklenen değerinden sapmalar şeklinde sayısal olarak ifade edilmektedir (Ayan \& Akay, 2013).

Modern Portföy Teorisi, risk ve belirsizlik altında yatırımcının yatırım kararı alırken göstermiş olduğu davranışların matematiksel modelini kurarken olasılık ve optimizasyon tekniklerini bir araya getirir. Modele göre bir portföyün getirisi ortalama getiri ile, riski ise varyans ile ölçülür. Ortalama-varyans analizi, amaç fonksiyonu ve kısıt yapısına sahip olması nedeniyle kısıtlı olanaklar dahilinde maksimum fayda sağlamak ya da maliyeti minimize etmek amaciyla kurulan bir modeldir (Keçeci, 2015).

Markowitz'e göre optimum portföy seçiminde "Etkin Sınır" kavramı söz konusudur. Belli bir getiri seviyesinde en düşük riske sahip ya da belli bir risk seviyesinde en yüksek getiriye sahip portföylerin bir araya getirilmesiyle oluşturulan eğrinin geometrik yerine etkin sınır denir (Markowitz, 1952). Etkin Sınır kavramında, her yatırımcının kabul edebileceği risk düzeyi farklı olduğu için her getiri oranı için en düşük risk seviyelerine sahip portföyleri içeren yatırım kümeleri oluşturulmaktadır. Yatırımcıların, Ortalama Varyans Modeli'ne göre oluşturulan etkin portföyler kümesinden belli bir risk ya da getiri seviyesinde en uygun şartları taşıyan portföyü seçmeleri gerekmektedir (Keskintürk, Demirci, \& Tolun, 2010). Bu sınır üzerinde yer alan bütün seçimler etkin portföyü oluştururken hangi portföyün seçileceği yatırımcının getiri için katlandığı risk düzeyi ile ilişkilendirilmektedir.

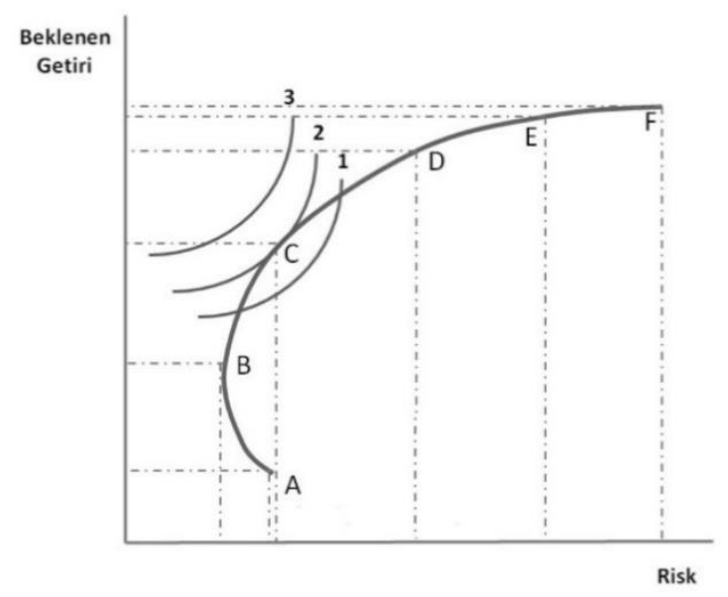

Şekil 3. Etkin sınır eğrisi 
Şekil 3'ten de anlaşılacağı üzere, A - B - C -D - E - F noktaları gibi aynı eğri üzerinde yer alan tüm portföyler etkin portföyler olup bu etkin portföylerin birleşiminden oluşan eğri etkin sinır eğrisidir. Bu eğrinin dışında kalan alanlarda portföy oluşturmak imkansızdır. Yine şekilde, 3 numaralı eğri için etkin portföy oluşturulamayacağ 1 numaralı eğrinin etkin sınır üzerinde olmadığı 2 numaralı eğri ile C noktasının etkin sınır üzerinde kesişerek optimum portföy bileşimini verdiği anlaşılmaktadır.

\section{Portföy Riski ve Performansının Ölçülmesi}

Risk kavramını oluşturan bileşenler incelendiğinde, var olan belirsizlik durumu ve bu belirsizliğe katlanma durumu görülmektedir. Belirsizliğin ölçülebilir miktarı riski oluşturur, ölçebiliyorsak müdahale etme imkanı oluşmaktadır. Belirsizlikle ilgili gerçekleşmemiş duruma dair olasılıkların tahmini kişisel bakış açısı ile yapılıyorsa belirsizlik, nesnel bir bakış açısıyla yapılıyorsa ölçülebilir bir durum yani risk oluşmaktadır. Yatırımcıların katlanmak zorunda kaldığ iki etkenden oluşur. Tüm dünyadaki finansal unsurları ilgilendiren ve yöneticilerin etki gücüne sahip olamayacağı risk sistematik risk, yönetim tarafından azaltılabilecek ve önlem alınabilecek risk ise sistematik olmayan risk olarak adlandırılır (Usta \& Demireli, 2012).

Finansal piyasalar bakımından risk; yatırım aracının gelecekteki değerinin yatırımcının hedeflediği değerin altında kalma ihtimalidir. Dönemler içerisinde gerçekleşen getiriler ile ilgili dönemlerdeki beklenen getiriler arasındaki farkın ölçülmesi riski ölçümlemede gerçekçi bir yaklaşım sağlamaktadır. Risk ölçümlemede kullanılacak bu dağılım ise varyans ve standart sapma ifade edilmektedir.

Portföy performansı ölçmek için de temel olarak getiri ve risk üzerine yoğunlaşılmıştır. Geçmişten günümüze yapılan çalışmalar ile performans ölçüm modelleri oluşturulmuş ve bu modeller belirli farklılıkları ile sınıflandırılmıştır. Sharpe oranı, Sortino oranı ve M-kare performans ölçütü toplam riske göre, yani sistematik ve sistematik olmayan riski birlikte değerlendirerek ölçüm yapan modellerdir. Treynor oranı, Jensen (Alfa) ölçütü, T-kare performans ölçütü ve Değerleme oranı sadece sistematik riski dikkate alarak performans ölçen modellerdir. CF VaR'a göre düzeltilmiş Sharpe oranı, potansiyel maksimum kayba göre performans ölçen bir modeldir. Fama ölçütü ise piyasa zamanlamasına göre performans ölçen bir modeldir.

\section{Yöntem}

Yatırım kararlarında getiri için katlanılacak risk, yatırım seçimlerinde geçmişten günümüze kaçınılmaz bir unsur olmuştur. Yapılan çalışmalarda ve bireysel ve toplu tercihlerin sonuçlarında birçok piyasada yatırımcının riskten kaçmasının çok zor olduğu görülmüştür. Riskin yüksek, sert iniş çıkışlar ile belirsizliklerin hat safhada olduğu kripto para piyasalarında ise bu zorluk daha yoğun bir şekilde yatırımcılar üzerinde baskı kurmaktadır.

\section{Araştırma Modeli}

Portföy teorileri yatırım risklerini yönetme ve mevcut riske göre getiriyi maksimize etme konusunda yoğunlaşırlar. Geleneksel portföy teorisi farklı yatırım araçları seçmenin riski azaltacağı yaklaşımıyla portföy yönetimi uygulanırken bu seçimler arasındaki ilişkileri hesaba katmamaktadır (Kapusuzoğlu \& İbicioğlu, 2013). Harry Markowitz 1952 yılında yayınlanan portföy seçimi ile ilgili makalesinde, farklı yatırım araçları kullanılarak yapılacak çeşitlendirme ile elde edilecek etkinliğe ve daha önemlisi bu çeşitliliği oluşturma yöntemine 
değinmiştir. Markowitz çalışmada aynı getiri düzeyinde olan portföyde riski en düşük seviyede tutmak için aralarında ters yönde ilişki olan yatırımların seçilmesi gereğinden söz eder. Aynı getiriyi sağlayan portföylerden riski düşük olanın seçilmesi, aynı riske sahip portföylerden getirisi yüksek olanın seçilmesi ve aynı yönde yüksek ilişkili yatırım araçlarının portföy içeriğine dahil edilmesinden kaçınmakla sistematik risk azaltılabilmekte hatta sıfırlanabilmektedir. Doğru bir çeşitlendirme ile portföyün riskini, portföyü oluşturan yatırım araçlarının riskinden daha düşük hale getirmek ve riski yok etmek mümkündür. Yatırım araçları içerisinde kripto paralara yer vererek çeşitlendirme yapmak ve risk yönetimi uygulamak ile elde edilebilecek sonuçlar bu çalışmada incelenmiştir.

Diğer bir inceleme konusu ise yatırım kararı öncesi karardan elde edilebilecek verimi incelemek, yatırım sonrasında ise elde edilen sonuçları değerlendirerek sonraki seçimlerde daha iyi kararlar vermek üzere yatırım üzerinde görüş oluşturmaktır. Bu performans ölçüm süreci portföyün belirli zaman aralığındaki performansını farklı zaman aralığı ile kıyaslayarak veya aynı zaman aralığındaki farklı portföylerin performansları ile karşılaştırılarak yapılabilmektedir. Yatırım başlangıcı ve sürekliliği açısından portföyün performansını ölçmek ve süreci gözlemlemek önem arz etmektedir (Teker, Karakurum, \& Tav, 2008).

Yatırımların performansının değerlenmesinde iki yaklaşım uygulanmaktadır. $\mathrm{Bu}$ yaklaşımlardan ilki yatırımların riske göre düzeltilmiş getirilerinin benzer amaçları taşıyan diğer yatırımların aynı şekilde hesaplanmış getirileri ile ya da ilgili yatırım performansını en iyi şekilde temsil eden bir referansın getirisi ile kıyaslanması ile uygulanmaktadır. Piyasa zamanlaması olarak adlandırılan ikinci yaklaşım ise yatırımlarda yer alan varlıkların doğru zamanda alınıp doğru zamanda satıldığının test edilmesidir (Korkmaz, Aydın, \& Sayılgan, 2013). Kripto para piyasalarında yer alan yatırım araçlarının, riske göre düzeltilmiş getirilerinin benzer amaçları taşıyan diğer yatırımların aynı şekilde hesaplanmış getirileri ile ya da ilgili yatırım performansını en iyi şekilde temsil eden bir referansın getirisi ile kıyaslanması ile elde edilebilecek sonuçlar da bu çalışmada incelenmiştir.

\section{Evren ve Örneklem}

Bu çalışmada evren ve örneklem olarak 2018 yıl sonu itibariyle kripto para piyasalarında en yüksek işlem hacmine sahip üç kripto para (Bitcoin, Ethereum, Ripple), ülkemizde en yüksek işlem hacmine sahip üç döviz kuru (Dolar, Euro, İngiliz Sterlini), ülkemizde yaygın olarak yatırım araçları içerisinde yer alan üç endeks (Borsa İstanbul XU100, Dow Jones Borsası DOW30, Alman Birleşik Borsa Endeksi DAX) ve işlem hacmi en yüksek üç emtia (Altın, Brent Petrol, Mısır) incelenmiştir. Aynı yatırım araçlarının 2019 yılı ilk 6 ay verileri ile ve 2019 yılı 12 aylık verileri ile iki kontrol grubu oluşturulmuştur.

$\mathrm{Bu}$ karar doğrultusunda, analizde 2018 yılsonundan geriye dönük verilere bakıldı̆̆ında 07.08.2015 tarihi itibari ile Ripple verilerin başlangıç tarihini belirlemektedir. Bu bilgiler 1şığında çalışmada baz veriler grubunda 07.08.2015 ile 31.12.2018 tarihleri arasında yer alan 1243 günlük veri incelenmiştir. İlk 6 aylık kontrol grubunda 01.01.2019 ile 30.06.2019 tarihleri arasında yer alan 181 günlük veriden yararlanılmıştır. İkinci kontrol grubunda ise 01.01.2019 ile 31.12.2019 tarihleri arasında yer alan 365 günlük veri kullanılmıştır. Bitcoin, Ethereum, Ripple, Dolar, Euro, İngiliz Sterlini, Borsa İstanbul XU100, Dow Jones Borsası DOW30, Alman Birleşik Borsa Endeksi DAX, Altın, Brent Petrol, Mısır yatırım araçlarının kapanış verileri serbest piyasa verilerinden yararlanılarak investing.com adresinden alınmıştır. Oluşturulan portföyler içerisinde her yatırım aracına eşit ağırlık verilmiştir. Risksiz faiz oranı olarak kabul 
edilen Hazine Bonosu Faiz Oranı ise Türkiye Cumhuriyeti Merkez Bankası verilerinden elde edilmiştir.

\section{Veri Toplama Araçları}

Araştırma için seçilen varlıkların kapanış verileri üzerinden ilgili yatırım araçları için ortalama getirileri, standart sapmaları, varyansları, beta katsayıları, kovaryansları, sistematik riskleri ve sistematik olmayan riskleri hesaplanmıştır.

Serbest piyasadan elde edilen günlük kapanış verileri mutlak getiri yöntemi ile şu şekilde hesaplanmıştır (Küçükkocaoğlu, 2002);

$$
\begin{gathered}
\qquad r_{i}=S_{t+1}-S_{t} \\
r_{i}=\text { Yatırımın } t \text { ve } t+1 \text { zaman dilimleri arasındaki getirisi } \\
S_{t}=\text { Yatırımın } t \text { zaman dilimindeki kapanıș verisi } \\
S_{t+1}=\text { Yatırımın } t+1 \text { zaman dilimindeki kapanıș verisi }
\end{gathered}
$$

Günlük getiriler ile hesaplanan ortalama getiri aritmetik ortalama yöntemi ile şu şekilde hesaplanmıştır (Küçükkocaoğlu, 2002);

$$
\begin{gathered}
r_{p}=\frac{r_{M_{1}}+r_{M_{2}}+r_{M_{3}}+\cdots+r_{M_{n}}}{n} \\
r_{p}=\text { Yattrtmin ortalama getirisi }
\end{gathered}
$$

Kantitatif bir risk ölçüm aracı olarak varyans ve standart sapma hesaplamalarında kullanılan formüller şöyledir (Küçükkocaoğlu, 2002);

$$
\begin{gathered}
\sigma_{r}^{2}=\frac{1}{n} \sum_{i=1}^{n}\left(r_{i}-\overline{r_{i}}\right)^{2} \\
\sigma_{r}^{2}=\text { Varyans } \\
\sigma_{r}=\sqrt{\frac{1}{n} \sum_{i=1}^{n}\left(r_{i}-\overline{r_{i}}\right)^{2}} \\
\sigma_{r}=\text { Standart sapma }
\end{gathered}
$$

Yatırım araçları arasındaki ilişkinin yönünü ölçmek için kovaryans, bu ilişkinin derecesini ölçmek için ise korelasyon katsayısı kullanılmıştır (Küçükkocaoğlu, 2002);

$$
\begin{gathered}
\operatorname{Cov}\left(r_{i}, r_{j}\right)=\frac{\sum_{i, j=1}^{n}\left(r_{i}-\overline{r_{i}}\right)\left(r_{j}-\overline{r_{j}}\right)}{n-1} \\
\rho_{\left(r_{i}, r_{j}\right)}=\frac{\operatorname{Cov}\left(r_{i}, r_{j}\right)}{\sigma_{r_{i}} \sigma_{r_{j}}}
\end{gathered}
$$

Yatırım aracının getirisinin, piyasa getirisine olan duyarlılığını ifade eden beta katsayısını bulmak için şu formül uygulanmıştır (Küçükkocaoğlu, 2002); 


$$
\begin{gathered}
\beta=\frac{\operatorname{Cov}\left(r_{i}, r_{M}\right)}{\sigma_{r_{M}}^{2}} \\
r_{M}=\text { Piyasa getirisi }
\end{gathered}
$$

Sistematik ve sistematik olmayan risk hesaplamalarını yapabilmek için ilgili formül Sharpe'ın çalışmasında ifade edilmiştir (Sharpe, 1994). Buna göre herhangi bir yatırım aracı için toplam riski ifade eden formül şu şekildedir;

$$
\begin{gathered}
\text { Toplam Risk = Sistematik Risk }+ \text { Sistematik Olmayan Risk } \\
\qquad \sigma_{r_{p}}^{2}=\beta_{p}^{2} \sigma_{r_{M}}^{2}+\sigma_{e_{p}}^{2}
\end{gathered}
$$

Her bir yatırım aracı için hesaplanan ortalama getiri, standart sapma, varyans, beta katsayısı, kovaryans, sistematik risk ve sistematik olmayan risk ilişkilendirilerek verilerin toplanması ve sınıflandırılması tamamlanmıştır.

\section{Verilerin Analizi}

Yatırım araçlarının performans değerlendirilmesinde uygulanan yöntemler toplam dört grupta sınıflandırılmıştır; toplam riske göre performans ölçen yöntemler, sistematik riske göre performans ölçen yöntemler, potansiyel maksimum kayba göre performans ölçen yöntemler ve piyasa zamanlamasına göre performans ölçen yöntemlerdir.

Sharpe oranı: En yaygın ve hızlı ölçüm yöntemi olan Sharpe Oranı, oynaklığa göre hesaplanan bir sonuç vermektedir (Liow, 1997). Yatırım aracı getirisinin risksiz faiz oranı üzerinden farkının yatırım aracının risk değerine bölünmesiyle elde edilmektedir. Bu oran sonucu elde edilecek endeks değerinin büyüklüğü, riske göre elde edilecek daha çok getiriyi ifade etmektedir. Şu formül ile hesaplanmaktadır (Sharpe, 1994);

$$
\begin{gathered}
S=\frac{r_{p}-r_{f}}{\sigma_{p}} \\
r_{f}=\text { Risksiz faiz oraml } \\
r_{p}=\text { Yattrimin ortalama getirisi } \\
\sigma_{p}=\text { Yattrmmin standart sapmasl }
\end{gathered}
$$

M-kare performans ölçütü: Standart sapmayı risk değeri olarak kullanan başka bir ölçüt ise Mkare performans ölçütüdür. Bu ölçütte yatırım araçları aynı oynaklık ile düzenlenerek değerlendirilir. Genel olarak piyasa oynaklığının kullanıldığı bu yöntemde yatırım araçları için düzenlenen getiri oranlarına bakarak (M-kare oranları) karşılaştırılabilirler. M-kare oranı aşağıdaki gibi formüle edilmektedir (Modigliani \& Modigliani, 1997).

$$
M^{2}=r_{p^{*}}-r_{m}
$$

Sharpe Oranı üzerinden bakılacak olursa şu şekilde hesaplanmaktadır (Scholz \& Wilkens, 2005);

$$
\begin{gathered}
M^{2}=(\text { Sharpe Orant }) \sigma_{m}-\left(r_{m}-r_{f}\right) \\
r_{m}=\text { Piyasa getirisi } \\
r_{f}=\text { Yattrimin faiz oranl }
\end{gathered}
$$




$$
\sigma_{m}=\text { Piyasa standart sapmasl }
$$

Sortino oranı: Bir yatırım varlığı, portföy veya stratejinin riske uyarlanmış getirisini ölçen diğer bir ölçüt ise Sortino Oranıdır. Bu model, Sharpe oranının bir modifikasyonudur. Sharpe oranı tüm oynaklığa eşit şekilde etki ederken, Sortino Oranı yalnızca kullanıcı tarafından belirlenen bir hedefin veya istenen getiri oranının altına düşen getirilere etki etmektedir (Sortino \& Price, 1994).

Sortino Oranına göre, standart sapma yerine aşağı yönde sapma kullanılır. Bu şekilde getiri dağılımlarının asimetrik olma problemine çözüm yaratmaktadır (Géhin, 2004).

$$
\begin{gathered}
S R=\frac{\bar{r}_{p}-M A R}{\sqrt{\sum_{t=1}^{T} \frac{\left(r_{p t}-M A R\right)^{2}}{T}}} \\
M A R=\text { Minimum } \text { kabul edilebilir değer } \\
\bar{r}_{p}=\text { Yatırımın ortalama getirisi } \\
r_{p t}=\text { Yatırımin } \text { t zamandaki getirisi } \\
T=\text { İncelenen aylarm sayısı }
\end{gathered}
$$

Treynor oranı: Kabul edilen her bir piyasa risk birimi başına çeşitlendirilebilir riski olmayan bir yatırımda kazanılabilecek getiri oranını ifade etmektedir. Temelde Sharpe Oranı ile aynı özelliği taşımaktayken, Treynor oranı risk ölçütü olarak beta katsayısını kullanmaktadır (Treynor, 1965). bu yöntemde Treynor, yatırım aracını iyi şekilde çeşitlendirilmiş olarak kabul ederek, riskin çeşitlendirilebileceğini göz ardı etmektedir. Sistematik olmayan riskini etki dışı birakmaktadir.

$$
\begin{gathered}
T=\frac{r_{p}-r_{f}}{\beta_{p}} \\
r_{p}=\text { Yatırım getirisi } \\
r_{f}=\text { Risksiz faiz oranı } \\
\beta_{p}=\text { Yatırımun sistematik riski }
\end{gathered}
$$

T-kare performans ölçütü: Treynor oranını yüzdelik getiri oranı gösterimine çeviren bu yöntem, M-kare yönteminde olduğu gibi değerlendirilen yatırım aracını risksiz faiz oranı ile düzenleyerek risk düzeltmesi yapmaktadır (Samarakoon \& Hasan, 2006). Yatırımın sistematik olmayan riskini etki dışı bırakmaktadır.

$$
\begin{gathered}
T^{2}=(\text { Treynor Oranl })-\left(r_{m}-r_{f}\right) \\
r_{m}=\text { Piyasa getirisi } \\
r_{f}=\text { Risksiz faiz oranl }
\end{gathered}
$$

Jensen (Alfa) ölçütü: Jensen ölçütü, yatırım aracının performansını tek bir değerle ölçmektedir. $\mathrm{Bu}$ ölçüt yatırım aracı getirileri ile pazar getirileri arasında kurulan regresyon denkleminin sabit terimi olan alfa katsayısıdır. Pozitif alfa katsayısı, yatırım aracının başarılı olduğunu, 
negatif alfa katsayısı ise başarısız olduğunu ifade etmektedir (Jensen, 1968). Yatırımın sistematik olmayan riskini etki dışı bırakmaktadır.

$$
\begin{gathered}
\alpha_{p}=\bar{r}_{p}-\left[\bar{r}_{f}+\beta_{p}\left(\bar{r}_{m}-\bar{r}_{f}\right)\right] \\
\alpha_{p}=\text { Jensen alfa değeri } \\
\bar{r}_{p}=\text { Yatırımın ortalama getirisi } \\
\bar{r}_{f}=\text { Ortalama risksiz faiz oran } \\
\bar{r}_{m}=\text { Ortalama piyasa getirisi }
\end{gathered}
$$

Değerleme oranı: Sistematik riske göre performans ölçen modellerde problemli olan taraf portföyün iyi çeşitlendirilmiş olduğu kabul edilerek sistematik olmayan riski etki dışı bırakmalarıdır. Değerleme oranında (Appraisal Ratio) ise yatırımın alfa oranı yatırımın sistematik olmayan riskine bölünerek bu düzeltme sağlanmaktadır (Hecht, 2014). İlgili formül şöyle gösterilmektedir;

$$
\begin{gathered}
A R=\frac{\alpha_{p}}{\sigma_{p}} \\
\alpha_{p}=\text { Jensen alfa değeri } \\
\sigma_{p}=\text { Sistematik olmayan risk }
\end{gathered}
$$

CF VaR a göre düzeltilmiş Sharpe oranı: Bu yöntemde, Cornish Fisher VaR değeri kullanarak Sharpe oranında yaşanan dağılımın yüksek momentlerini etkiye alamama sorununu düzeltmek için Sharpe oranının paydası CF VaR ile değiştirilmiş ve Düzeltilmiş Sharpe Oranı hesaplanmıştır. Bu metodla sistematik olmayan riske göre performans ölçen Sharpe oranı, potansiyel maksimum kayba göre performans ölçümüne uyarlanmıştır (Sharma, 2005).

Cornish Fisher VaR değeri iki aşamada hesaplanmaktadır (Maillard, 2012). İlk aşamada Cornish Fisher $\mathrm{Z}$ değeri bulunmaktadır;

$$
Z_{c f}=Z+\frac{1}{6}\left(Z^{2}-1\right) S+\frac{1}{24}\left(Z^{3}-3 Z\right) K-\frac{1}{36}\left(2 Z^{3}-5 Z\right) S^{2}
$$

Bu denklemde $\mathrm{Z}$ normal dağılıma ait kritik değeri, S (skewness) eğiklik ve K (kurtosis) diklik değerini ifade eder. Bu hesaplamanın amacı veri dağılımına daha uygun bir güven düzeyi hesaplamaktır (Teker, Karakurum, \& Tav, 2008). İkinci aşama ise CF VaR hesaplamasının yapilmasidir;

$$
C F V a R=P V * \sigma * Z_{c f} * \sqrt{H P}
$$

Formülde PV yatırımın piyasa değerini, HP elde tutma süresini ifade etmektedir. Bu veriler eklenerek oluşturulan CF VaR a göre düzeltilmiş Sharpe oranı şöyledir (Sharma, 2005);

$$
\begin{gathered}
M S=\frac{r_{p}-r_{f}}{C F \text { VaR }} \\
r_{p}=\text { Yaturum getirisi } \\
r_{f}=\text { Risksiz faiz orant }
\end{gathered}
$$


Fama ölçütü: Eugene Fama, 1972 yılında beklenen getiriyi aşan getiriyi, toplam risk primine göre ölçmüştür. Yatırım fonu performansının yöneticinin seçicilik ve zamanlama yeteneğine bağlı olarak belirlendiğini göstermiştir (Fama, 1972). Fama ölçütünde bir yatırımın getirisini ve performansını belirleyen dört temel bileşen bulunmaktadır. Bu bileşenler risksiz faiz oranı, toplam risk etkisi, mükemmel çeşitlendirme yapılamamasının etkisi ve yatırımcının seçicilik becerisinin kazandırdığı net getiri olarak sıralanmaktadır (Yücel, 2016).

$$
\begin{gathered}
F_{p}=\text { Fon Getirisi - Risksiz Getiri }- \text { Toplam Riske Göre Getiri } \\
\qquad \begin{array}{c}
F_{p}=\left(r_{p}-r_{f}\right)-\left[\frac{\sigma_{p}}{\sigma_{m}}\right]\left(r_{m}-r_{f}\right) \\
r_{p}=\text { Yattrmm getirisi } \\
r_{f}=\text { Risksiz faiz oranl } \\
r_{m}=\text { Piyasa getirisi } \\
\sigma_{p}=\text { Yattrumin standart sapmast } \\
\sigma_{m}=\text { Piyasa standart sapmasl }
\end{array}
\end{gathered}
$$

Optimal Portföy ve Etkin Sınır: Birden fazla yatırım aracının getirisi, her bir yatırım aracının getirilerinin aritmetik ortalaması ile yatırım aracının toplam bileşendeki oranı çarpılarak bulunabilmektedir. Ancak birden fazla yatırım aracının riski hesaplanmak istendiğinde durum bu hesaplamadan biraz daha karmaşık olmaktadır. Bunun sebebi Markowitz'in savunduğu üzere, kullanılan yatırım araçlarının risklerinin aralarındaki ilişkinin yönüne ve şiddetine esasen yatırım araçları toplamının riskini beklendik veya beklenmedik yönde etkileyebilmesidir. Bu sebeple birden fazla yatırım aracının riski hesaplanırken aralarındaki bağ da dikkate alınmaktadır. Birden fazla yatırım aracının getirisinin ve riskinin bulunmasında aşağıdaki formüller uygulanmaktadır (Kardiyen, 2008);

$$
\begin{gathered}
E\left(r_{p}\right)=\sum_{i=1}^{n} E\left(r_{i}\right) x_{i} \\
E\left(r_{p}\right)=\text { Port } f \text { öyün beklenen getirisi } \\
x_{i}=\text { i yatırım aractnın bileşendeki oranı } \\
\sigma_{p}^{2}=\sum_{i=1}^{n} \sum_{j=1}^{n} \operatorname{cov}\left(r_{i}, r_{j}\right) x_{i} x_{j} \\
\operatorname{cov}\left(r_{i}, r_{j}\right)=i \text { ve } j \text { yatırtm araçlarının getirilerinin kovaryansı } \\
n=\text { mevcut yatırım aract sayısı }
\end{gathered}
$$

Markowitz, yatırımcının amacının beklediği getiriyi elde ederken, edineceği riski en aza indirgemek olduğunu öne sürmüştür. Bu bilgiler ışı̆̆ında, birden fazla yatırım aracının dahil olduğu bileşen için optimum bileşen için hesaplanan formül ve oluşturulan kısıtlar şöyledir (Markowitz, 1952); 


$$
\begin{aligned}
& \min \sum_{i=1}^{n} \sum_{j=1}^{n} x_{i} x_{j} \sigma_{i j} \\
& \sum_{i=1}^{n} x_{i} \mu_{i} \geq R \\
& \sum_{i=1}^{n} x=1 \\
& 0 \leq x_{i} \leq 1 \quad i=1,2, \ldots n \\
& \mu_{i}=i \text { yaturım aractnın beklenen getirisi }(i=1,2, \ldots n) \\
& R=\text { hedeflenen beklenen getiri düzeyi }
\end{aligned}
$$

Formüllerde, minimize edilmek istenen amaç fonksiyonu, yatırım aracının hedeflenen beklenen getirisi ile bileşendeki her bir yatırım aracının çarpımlarının toplamı uygulanırken, bileşendeki yatırım araçlarının ağırlıklarının toplamının 1 olması gerektiğine dair kısıt ifade edilmiştir.

İlgili hesaplamalarla oluşturulan söz konusu bileşenler, verilen ve ya daha yüksek beklenen getiri ve verilen ve ya daha düşük risk için maksimum beklenen getiriye sahiptir ve bu bileşenler etkin portföyler olarak adlandırılmaktadırlar. Etkin portföy tarafından elde edilen beklenen getiri ve risk, etkin ortalama-varyans bileşeni olarak adlandırılmaktadır. Tüm etkin ortalama-varyans kombinasyonları kümesi de "etkin sınır" olarak ifade edilmektedir (Jacobs, Levy, \& Markowitz, 2005). Bu bilgiler 1şığında, beklenen getiri seviyesinde en düşük risk sağlayan yatırım aracı bileşimi etkin sınırda yer almaktadır. Etkin sınır, her bir beklenen getiri seviyesinde, yatırımcılara uygun yatırım aracı seçmede en iyi seçeneği sağlamaktadır (Fernández \& Gómez, 2007).

\section{Bulgular}

Baz verilere ait ilgili portföy performans ölçüm modelleri sonuçlarının büyükten küçüğe sıralanmış ve Tablo 1'de verilmiştir.

Tablo 1. Baz Verilere Ait Portföy Performans Ölçüm Modellerinin Karşılaştırılması

\begin{tabular}{lllllllll}
\hline Sharpe & Treynor & Jensen & M2 & T2 & Sortino & $\begin{array}{l}\text { Değerl. } \\
\text { Oranı }\end{array}$ & Fama & MS \\
\hline Optimum & XRP & XRP & Optimum & XRP & Optimum & Tümü & XRP & GBP \\
Kripto & Kripto & ETH & Kripto & Kripto & Kripto & Optimum & ETH & BRENT \\
Tümü & BTC & Kripto & Tümü & BTC & Tümü & Kripto & Kripto & Corn \\
ETH & Tümü & Optimum & ETH & Tümü & ETH & BTC & Optimum & Emtia \\
XRP & GBP & BTC & XRP & GBP & XRP & ETH & BTC & Gold \\
BTC & Kur & Tümü & BTC & Kur & BTC & XRP & Tümü & DAX \\
EUR & USD & Endeks & EUR & USD & EUR & EUR & EUR & Endeks \\
USD & EUR & XU100 & USD & EUR & USD & Endeks & USD & Dow30
\end{tabular}




\begin{tabular}{lllllllll} 
Kur & Endeks & EUR & Kur & Endeks & Kur & USD & BRENT & XU100 \\
GBP & XU100 & USD & GBP & XU100 & GBP & BRENT & Kur & Tümü \\
BRENT & Dow30 & Kur & BRENT & Dow30 & BRENT & Kur & GBP & BTC \\
XU100 & DAX & Dow30 & XU100 & DAX & XU100 & XU100 & XU100 & Kripto \\
Dow30 & Emtia & GBP & Dow30 & Emtia & Dow30 & GBP & Dow30 & Optimum \\
Gold & BRENT & BRENT & Gold & BRENT & Gold & Dow30 & Gold & Kur \\
Corn & Corn & Emtia & Corn & Corn & Corn & Corn & Emtia & ETH \\
Emtia & Gold & Gold & Emtia & Gold & Emtia & Gold & Corn & USD \\
Endeks & Optimum & DAX & Endeks & Optimum & Endeks & Emtia & Endeks & EUR \\
DAX & ETH & Corn & DAX & ETH & DAX & DAX & DAX & XRP \\
\hline
\end{tabular}

Tablo incelendiğinde tüm portföy performans ölçüm modellerinde en iyi yatırım aracını kripto paralar ve kripto paraların içeriğini oluşturduğu veya içeriğinde bulunduğu portföylerin oluşturduğu görülmektedir. Tabloda kripto paralar mavi, kripto portföyü turuncu, optimum portföy yeşil, tüm varlıkların yer aldığ1 portföy ise sarı renklendirilmiştir.

Baz alınan tarihler aralığında ilgili on iki temel yatırım aracının katıldığı optimum portföy hesaplamasının sonuçları Tablo 2' de verilmiştir.

Tablo 2. Baz Verilere Ait Optimum Portföy Hesaplaması Sonuçları

\begin{tabular}{ll}
\hline Optimum Portföy & Ağırlık \\
\hline BTC & 0,2157554 \\
ETH & 0,2391546 \\
XRP & 0,158075 \\
USD & 0 \\
EUR & 0,387015 \\
GBP & 0 \\
XU100 & 0 \\
Dow30 & 0 \\
DAX & 0 \\
Gold & 0 \\
BRENT & 0 \\
Corn & 0 \\
Toplam & 1 \\
Beklenen Getiri & 1,1935069 \\
Standart Sapma & 0,0295757 \\
Ylllk Standart Sapma & 0,5650437 \\
Hazine Bonosu & 0,1839 \\
\hline
\end{tabular}

Tablo incelendiğinde optimum portföyü oluşturan dört yatırım aracından üçünün kripto paralardan oluştuğunu ve portföyün \%61ini oluşturduğu görülmektedir. Portföye katılan diğer yatırım aracının ise \%39 a yakın bir oran ile EUR olduğu görülmektedir. 


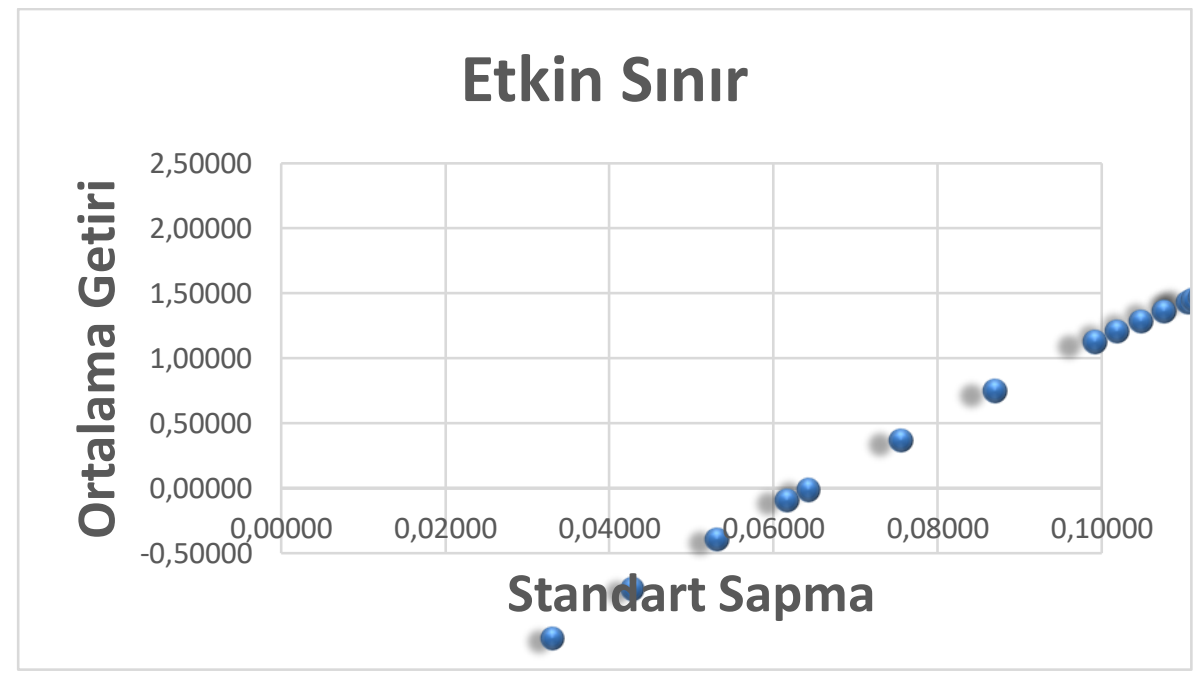

Şekil 4. Baz verilere ait etkin sınır eğrisi

Optimum portföy ile oluşturulan etkin sınır eğrisi ise üstte, şekilde gösterilmiştir.

İlk 6 ay kontrol verilerine ait portföy performans ölçüm modelleri sonuçlarının büyükten küçüğe sıralanmış ve Tablo 3 'te verilmiştir.

Tablo 3. İlk 6 Ay Kontrol Verilerine Ait Portföy Performans Ölçüm Modellerinin Karşılaştırılması

\begin{tabular}{lllllllll}
\hline Sharpe & Treynor & Jensen & M2 & T2 & Sortino & $\begin{array}{l}\text { Değerl. } \\
\text { Oranı }\end{array}$ & Fama & MS \\
\hline BTC & DAX & DAX & BTC & DAX & BTC & Dow30 & DAX & EUR \\
Optimum & Endeks & Endeks & Optimum & Endeks & Optimum & Emtia & Endeks & Kur \\
ETH & Tümü & BTC & ETH & Tümü & ETH & Optimum & BTC & USD \\
Kripto & XRP & ETH & Kripto & XRP & Kripto & BTC & ETH & GBP \\
Tümü & Emtia & Kripto & Tümü & Emtia & Tümü & BRENT & Kripto & Tümü \\
DAX & Corn & Tümü & DAX & Corn & DAX & Kripto & Tümü & DAX \\
Endeks & EUR & Optimum & Endeks & EUR & Endeks & ETH & Optimum & XU100 \\
BRENT & Dow30 & XRP & BRENT & Dow30 & BRENT & Tümü & XRP & Endeks \\
Emtia & GBP & BRENT & Emtia & GBP & Emtia & Corn & BRENT & Dow30 \\
Dow30 & Kur & Emtia & Dow30 & Kur & Dow30 & XRP & Emtia & Gold \\
XRP & USD & Dow30 & XRP & USD & XRP & Endeks & Dow30 & BTC \\
Corn & XU100 & Corn & Corn & XU100 & Corn & Gold & Corn & Corn \\
Gold & Gold & Gold & Gold & Gold & Gold & DAX & Gold & Kripto \\
USD & Optimum & XU100 & USD & Optimum & USD & XU100 & USD & Optimum \\
GBP & BRENT & USD & GBP & BRENT & GBP & GBP & Kur & Emtia \\
Kur & ETH & GBP & Kur & ETH & Kur & USD & GBP & ETH \\
EUR & BTC & Kur & EUR & BTC & EUR & Kur & EUR & BRENT \\
XU100 & Kripto & EUR & XU100 & Kripto & XU100 & EUR & XU100 & XRP \\
\hline & & & & & & & & \\
\hline
\end{tabular}


Tablo incelendiğinde tüm portföy performans ölçüm modellerinde en iyi yatırım aracını kripto paralar ve kripto paraların içeriğini oluşturduğu veya içeriğinde bulunduğu portföylerin oluşturduğu görülmektedir. Tabloda kripto paralar mavi, kripto portföyü turuncu, optimum portföy yeşil, tüm varlıkların yer aldığı portföy ise sarı renklendirilmiştir.

İlk 6 ay kontrol verilerini içeren tarihler aralığında ilgili on iki temel yatırım aracının katıldığ optimum portföy hesaplamasının sonuçları ise Tablo 4 'te verilmiştir.

Tablo 4. İlk 6 Ay Kontrol Verilerine Ait Optimum Portföy Hesaplaması Sonuçları

\begin{tabular}{ll}
\hline Optimum Portföy & Ağırlı \\
\hline BTC & 0,39 \\
ETH & 0 \\
XRP & 0 \\
USD & 0 \\
EUR & 0 \\
GBP & 0 \\
XU100 & 0 \\
Dow30 & 0,28 \\
DAX & 0,01 \\
Gold & 0 \\
BRENT & 0,19 \\
Corn & 0,13 \\
Toplam & 1 \\
Beklenen Getiri & 0,0033839 \\
Standart Sapma & 0,015506 \\
Y1llk Standart Sapma & 0,2962426 \\
Hazine Bonosu & 0,000595 \\
\hline
\end{tabular}

Tablo incelendiğinde optimum portföyü oluşturan beş yatırım aracından birinin kripto paralardan oluştuğunu ve portföyün \%39 unu oluşturduğu görülmektedir. Diğer \%61 oranını ise Dow30, DAX, BRENT ve Corn yatırım araçları oluşturmaktadır.

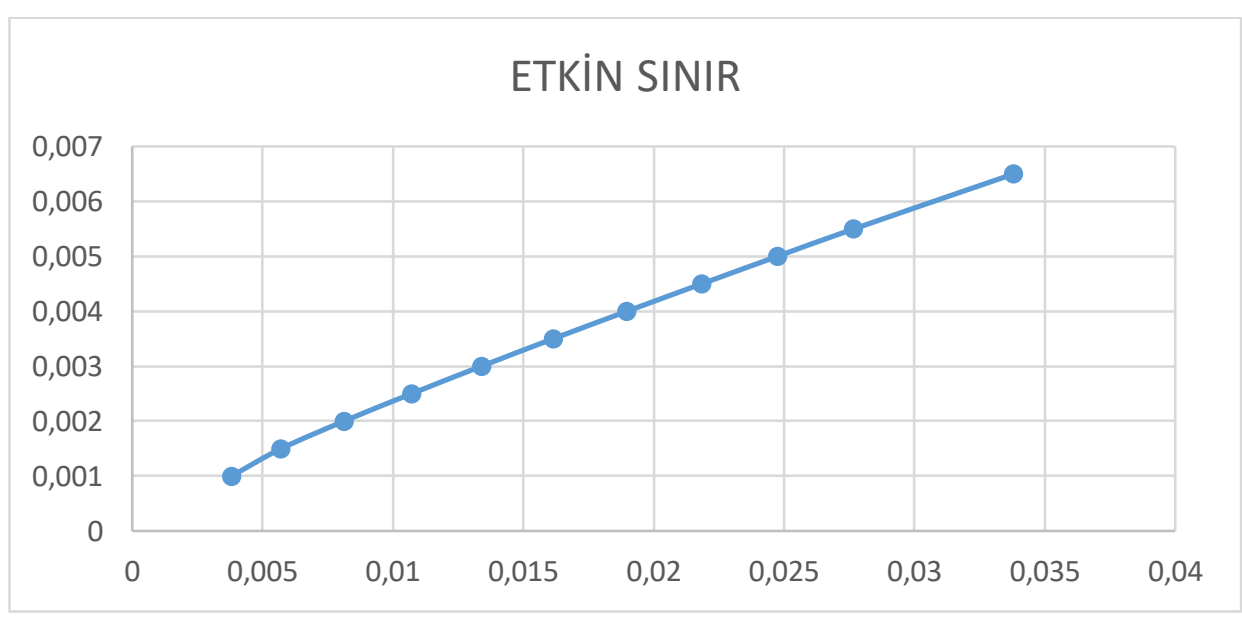

Şekil 5. İlk 6 ay kontrol verilerine ait etkin sınır eğrisi 
Optimum portföy ile oluşturulan etkin sınır eğrisi ise üstte, şekilde gösterilmiştir.

12 aylık verilere ait portföy performans ölçüm modelleri sonuçlarının büyükten küçüğe sıralanmış ve Tablo 5 'te verilmiştir.

Tablo 5. 12 Aylık Verilere Ait Portföy Performans Ölçüm Modellerinin Karşılaştırılması

\begin{tabular}{lllllllll}
\hline Sharpe & Treynor & Jensen & M2 & T2 & Sortino & $\begin{array}{l}\text { Değerl. } \\
\text { Oranı }\end{array}$ & Fama & MS \\
\hline BTC & DAX & DAX & BTC & DAX & BTC & Gold & DAX & XRP \\
Tümü & Endeks & Endeks & Tümü & Endeks & Tümü & Dow30 & Endeks & EUR \\
Endeks & Tümü & BTC & Endeks & Tümü & Endeks & Kur & BTC & Corn \\
DAX & XRP & Tümü & DAX & XRP & DAX & USD & Tümü & Tümü \\
Dow30 & BRENT & ETH & Dow30 & BRENT & Dow30 & GBP & Dow30 & DAX \\
XU100 & Corn & Kripto & XU100 & Corn & XU100 & EUR & XU100 & Endeks \\
Gold & Dow30 & Optimum & Gold & Dow30 & Gold & BTC & Gold & XU100 \\
BRENT & XU100 & BRENT & BRENT & XU100 & BRENT & Tümü & GBP & Dow30 \\
GBP & EUR & GBP & GBP & EUR & Emtia & BRENT & BRENT & Kripto \\
Optimum & USD & Gold & Optimum & USD & GBP & Optimum & Kur & BTC \\
Kripto & Kur & Kur & Kripto & Kur & Optimum & Emtia & USD & Optimum \\
ETH & GBP & USD & ETH & GBP & Kripto & Endeks & EUR & Emtia \\
Emtia & Gold & Emtia & Emtia & Gold & ETH & Kripto & Emtia & Gold \\
Kur & Optimum & Dow30 & Kur & Optimum & Kur & ETH & Optimum & ETH \\
USD & Emtia & EUR & USD & Emtia & USD & DAX & Corn & BRENT \\
EUR & Kripto & XU100 & EUR & Kripto & EUR & XU100 & Kripto & USD \\
Corn & ETH & Corn & Corn & ETH & Corn & Corn & ETH & Kur \\
XRP & BTC & XRP & XRP & BTC & XRP & XRP & XRP & GBP \\
\hline
\end{tabular}

Tablo incelendiğinde tüm portföy performans ölçüm modellerinde en iyi performans sunan yatırım araçları arasında kripto paralar bulunduğu ve kripto paraların içeriğini oluşturduğu veya içeriğinde bulunduğu portföylerin oluşturduğu görülmektedir. Tabloda kripto paralar mavi, kripto portföyü turuncu, optimum portföy yeşil, tüm varlıkların yer aldığı portföy ise sarı renklendirilmiştir.

12 aylık kontrol verilerini içeren tarihler aralığında ilgili on iki temel yatırım aracının katıldığ optimum portföy hesaplamasının sonuçları ise Tablo 6 ' da verilmiştir. 
Tablo 6. 12 Aylık Verilere Ait Optimum Portföy Hesaplaması Sonuçları

\begin{tabular}{ll}
\hline Optimum Portföy & Ağırlık \\
\hline BTC & 0,08 \\
ETH & 0 \\
XRP & 0 \\
USD & 0,01 \\
EUR & 0 \\
GBP & 0,13 \\
XU100 & 0,17 \\
Dow30 & 0,33 \\
DAX & 0,01 \\
Gold & 0,24 \\
BRENT & 0,02 \\
Corn & 0 \\
Toplam & 1 \\
Beklenen Getiri & 0,0007818 \\
Standart Sapma & 0,0046621 \\
Yıllık Standart Sapma & 0,0890688 \\
Hazine Bonosu & 0,0003151 \\
\hline
\end{tabular}

Tablo incelendiğinde optimum portföyü oluşturan sekiz yatırım aracından birinin kripto paralardan oluştuğunu ve portföyün \%8 ini oluşturduğu görülmektedir. Çoğunluğu oluşturan Dow30 ve diğer yatırım araçları ise USD, GBP, XU100, DAX, Gold ve BRENT olmuştur.

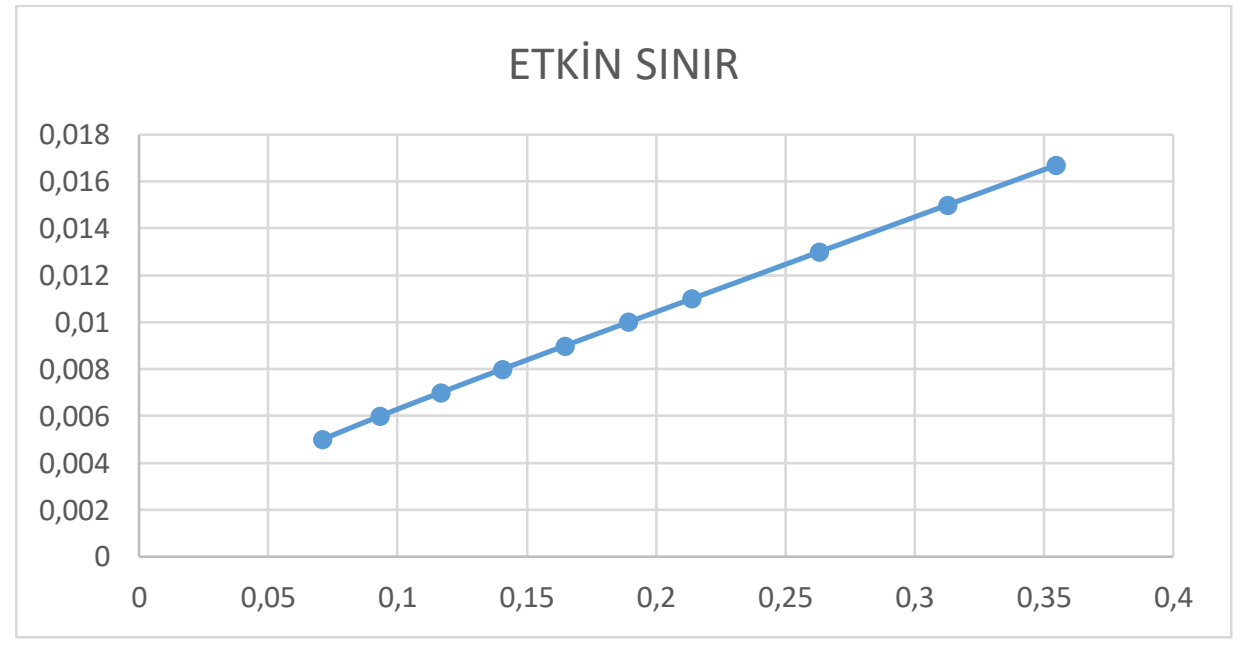

Şekil 6. 12 aylık verilere ait etkin sınır eğrisi

Optimum portföy ile oluşturulan etkin sınır eğrisi üstte, şekilde gösterilmiştir.

\section{Sonuç ve Öneriler}

Kripto paralar kelime anlamı ile 'cryptocurrency', 'crypto' ve 'currency' kelimelerinin birleşimi ile ifade edilir olmuşyur. Kripto para; mülkiyet haklarını korumak için kriptoloji (şifreleme) kullanan sanal bir para birimidir. Kripto paralar, merkezi olmayan şifrelenmiş sistemlerde, belirlenen miktarlarda ve her bir kripto para birimine özel belirlenen koşullara 
bağlı şartlarda üretilirler. Bu şifreleme hem kayıt güvenliğini sağlamak için hem de yeni para üretimi sürecinde kullanılmaktadır. Kişisel şifrelenmiş kayıtlarda tutulan kripto paralar için banka hesabına ihtiyaç yoktur. Ayrıca kripto paraların el değiştirmesi için banka gibi aracı diğer herhangi bir kuruma da ihtiyacı yoktur.

Kripto paraların portföy riskine ve getirisine etkilerininin ölçüldüğü ve yorumlandığ bu çalışmada kripto paraların yatırımcılar için faydalı portföy aracı olarak kullanılabilirliği araştırılmış, aktif para birimi olarak kullanımlarına yönelik incelemelerde bulunulmuştur. Yazınsal araştırmalar ile doğrudan devlet müdahalesine tabi tutulamayan sanal para birimleri olan kripto paraların reel ekonomiye doğrudan etki etme gücüne sahip olduğu tekrar anlaşılmıştır. İşlem masrafları yok denecek kadar az olan ve kısa sürede çok yüksek işlem hacimlerine ulaşan kripto paraların bu işlem düzeyine ulaşmasında yatırımcıların yüksek oynaklık düzeylerini fırsata çevirme çabaları olduğu ulaşılan sonuçlardan bir diğeridir.

Kripto paraların portföy riski ve getirisine etkilerini bilimsel olarak incelemek yatırımcıların karar alma süreçlerinde doğru kararlar vermelerine yardımcı olmak açısından önemlidir. Evren ve örneklem olarak 2018 yıl sonu itibariyle kripto para piyasalarında en yüksek işlem hacmine sahip üç kripto para (Bitcoin, Ethereum, Ripple), ülkemizde en yüksek işlem hacmine sahip üç döviz kuru (Dolar, Euro, İngiliz Sterlini), ülkemizde yaygın olarak yatırım araçları içerisinde yer alan üç endeks (Borsa İstanbul XU100, Dow Jones Borsası DOW30, Alman Birleşik Borsa Endeksi DAX) ve işlem hacmi en yüksek üç emtia'nın (Altın, Brent Petrol, Mısır) incelendiği bu araştırmada portföy performans ölçüm modelleri ile baz veriler için karşımıza çıkan sonuçlarda kripto paraların tüm yatırım seçimlerinde etkin rol oynadığını göstermektedir. Bu etkinlik çarpıcı bir şekilde tüm değerlemelerde üst sıralara ulaşacak kadar yüksektir. Yine baz alınan veriler için optimum portföy hesaplaması yapıldığında portföyün \%61'ini kripto paraların oluşturması bu sonucu desteklemektedir. Baz veriler için elde edilen bir diğer sonucu ise etkin sınır grafiği vermektedir; risk (standart sapma) arttıkça getiri artmaktadır.

İlk 6 aylık kontrol grubu verilerinin analizinden elden edilen bulgulardan toplam riske göre performans ölçen metotlarda kripto paraların baz verilerle yapılan ölçümlerdeki verimliliğini tam olarak sağlayamasa da performans ölçümlerinde üst sıraları koruduğu anlaşılmaktadır. Fakat sistematik riske göre performans ölçen, potansiyel maksimum kayba göre performans ölçen ve piyasa zamanlamasına göre performans ölçen modellerde tercih edilebilirlik düşmektedir. Bu durumun sebebi olarak sistematik riskin, yani genel ekonomik koşullardan kaynaklanan ve dolayısıyla tüm yatırım araçlarını etkileyen, kaçınılamayan riskin arttığı sonucuna varılmaktadır. Portföy performans ölçümlerinin akabinde optimum portföy incelemesi yapıldığında bu konjonktür altında kripto paralarının \%39 düzeyinde portföy içerisinde yer aldığının görülmesi portföy içerisindeki payının baz alınan yıla göre düşmesine rağmen kripto paraların tercih edilebilirliğini arttırdığı düşünülmektedir. İlk 6 aylık kontrol grubu için etkin sınıra baktığımızda daha keskin artan risk-getiri eğrisi sonucuna ulaşılmaktadır. Bu keskinliğin sistematik riskin artışından kaynaklandığı düşünülmektedir.

12 aylık veriler ile oluşturulan kontrol grubu verilerinin bulgu ve yorumlarını incelediğimizde, ilk 6 aylık kontrol grubu verilerinde karşılaştığımız gidişatın artarak devam ettiği görülmektedir. Performans ölçüm modelleri, toplam riske göre ölçümlerde kripto para bileşimini barındırırken, sistematik riske göre performans ölçen, potansiyel maksimum kayba göre performans ölçen ve piyasa zamanlamasına göre performans ölçen modellerde kripto para tercih edilebilirliği alt siralara düşmeye devam etmektedir. Artan sistematik riskin 
etkisini 12 aylık veriler ile oluşturulan kontrol grubunun optimum portföy incelemesinde karşılaştığımız altının portföy içerisindeki artışı da kanıtlar niteliktedir. Sistematik risk artışının etkisini iyice keskinleşen 12 aylık kontrol verileri grubuna ait etkin sınır eğrisi de göstermektedir. Sistematik riskteki bu artışın devam etmesine rağmen optimum portföy içeriğinde kripto para bileşeni mevcudiyetini koruması kripto paraların yatırım tercihlerinde ne kadar önemli olduğunu bir kez daha ortaya koymaktadır. Bu dönemde gerçekleşen risk artışını Covid-19 ile ilişkilendiren ve anlamlı ilişki bulan çalışmalar mevcuttur. Araştırma sonuçlarında Covid-19 döneminde risk artışı görülmesi ile Covid-19'un portföy içeriğindeki değişikliğe etki ettiği düşünülmektedir. Ayrıca çalışmanın sadece Covid-19 öncesi ve sonrası dönem ile araştırılarak bu konunun irdelenmesinin yerinde olacağı düşünülmektedir. Ulaşılan bulgularda, kripto paraların portföy çeşitlendirmesi açısından iyi bir varlık olabileceğini ifade eden literatürdeki çalışmaların sonuçları ile uyumlu olduğu görülmektedir.

Günümüz ekonomisinde yüksek işlem düzeyi ile ekonomilere etkisinin anlaşılması, kripto paraların risk-getiri düzeyinin yani artan riske karşı sağladığı getirinin incelenen diğer yatırım araçlarından daha fazla olduğunun anlaşılması, artan sistematik riske karşı yatırım araçlarının içerisinde yer bulabilmesi ile iyi bir yatırım aracı seçeneği oluşturabilmesi ve devletler tarafından bir para birimi statüsü ile kullanımına hukuki olarak imkan verilemeyeceğinin anlaşılması ile yatırım aracı olarak ekonomilerde yer alacağı düşünüldüğünde bu çalışmadan elde edilen sonuçların gelecekte tüm kullanıcılara bilgi sağlayacağı düşünülmektedir. Devletlerin senyoraj hakkı ile tek ve mutlak güç olarak dilediği gibi para üretimi sağlaması, her türlü politik kararların para birimlerine etkisi düşünüldüğünde kripto paralar bu etkilerden kurtulmak isteyen yatırımcılar için bir çıkış yolu oluşturabilmektedir. Daha az sistematik riske maruz kalmak her yatırımcı için değerli bir fırsat olacaktır. Bu sebeple portföy içeriğinde kripto para birimi tercihlerinde sistematik ve sistematik olmayan riskleri ayırarak portföy performanslarını incelemek faydalı bilgi sağlamaktadır. Arzı sabit ve enflasyondan etkilenmeyen, politik risklerden arındırılmış bir kripto paranın toplumun tümüne etki etmesi ve herkes tarafından global bir para birimi olarak kullanılması gün geçtikçe daha mümkün görünmektedir. Tüm bunlarla birlikte para değişimlerinin aracısız, sadece ağdan ağa iletişim ile minimum gecikme ile yapılması kripto paralara ilgiyi her geçen gün artırmaya yetecektir.

Kripto paraların tanınırlığı ve kabul edilebilirliği arttıkça değer kazandığı ve yatırımclarına sağladıkları getirinin de arttığı görülmektedir. Baz veriler, 6 aylık kontrol verileri ve 12 aylık kontrol verileri ile yapılan optimum portföy hesaplamalarında Bitcoin'in portföy içerisindeki payı da bu sonucu destekler niteliktedir. Kripto paraların ülkemizde tanınması ve kabul edilebilirliğinin artması kullanıcılarının bilgisayar ve internet ağları bilgilerine sahip olması ile de bağlantılıdır. Bu etmen aynı zamanda kripto para piyasasına ilgi gösterecek demografik grubu da şekillendirmektedir. Ülkemizde bilgisayar ve internet ile geç yaşta tanışan nüfusun kripto paralara karşı daha mesafeli bir tutum sergilemesi olağandır.

Geleneksel finans yatırım araçlarından farklı niteliklere sahip kripto para yatırım araçlarını, içinde bulunduğu potansiyel fayda ve kullanım alanlarının nasıl bir kazanç sağlayacağı anlaşılamayan durumdan çıkartarak yatırımcıların ve diğer kullanıcılar tarafından anlaşılması, yatırımcıların ve diğer kullanıcıların faydasına sunulması açısından portföy teorileri ve modern portföy yaklaşımı kullanılarak bir açıklama getirmek bu çalışmada hedeflenmiş ve sonuçları irdelenmiştir. Daha fazla ve çeşitli yöntemler ile kripto paralar üzerine çalışmalar yaparak tüm bulguların bir arada incelendiği ve daha derin veri aralığ1 ile her an değişim içerisinde olan bu sıra dışı ekonomik sistemde belirsizlikleri kaldırmak gerek 
son kullanıcılar için gerek akademik araştırmalar için yön gösterici olabilecektir. Bu kapsamda binlerce kripto para içerisinden işlem hacmi en yüksek üç kripto paranın etkileri ile analiz edilen bu çalışmayı, daha volatil kripto paralar ile farklılaştırmak başka sorulara da yanıt sağlayabilecektir. Ayrıca aynı yatırım araçlarını farklı analiz yöntemleri ile ölçüp karşılaştırmak da yeni cevaplar karşımıza çıkarabilecektir. Bu bilgiler ışığında araştırmacılar için bu sahada çokça ve birbirinin tekrarına düşmeyen araştırma yönlerinin varlığı da göz önüne alındığında yeni ve özgün çalışmalar yaparak çalışmalarını tamamlanan diğer çalışmalar ile karşılaştırmaları ve bu ekonomik sistemdeki belirsizlikleri gidermeye katkı sağlamaları tavsiye edilmektedir. Bu araştırmada her bir yatırım aracı önce portföy içerisinde eşit ağırlıklandırılmış ve daha sonra optimum ağırlıklandırma bulunmuştur. Yatırım araçlarına verilen ağırlıklar araştırmalarımızda önemli bir kısıtı oluşturmaktadır. Yeni arayışlar ve araştırma fikirleri ile ağırlıkların farklılaştırılması ve/veya portföy içeriğinin farklılaştırılması ile elde edilecek yeni bulgular kripto paralar hakkında faydalı bilgiler sağlayacaktır. Kripto paraları işletme finansmanı açısından değerlendiren kuruluşlar, bireysel yatırımcılar ve diğer son kullanıcılar için ise kripto para yatırım araçlarındaki oynaklık ile yüksek riski gözeterek karar almaları ve kripto paraların yatırımlarını çeşitlendirmede önemli bir varlık olacağı bulguları ile yatırımlarında mutlak suretle yer vermeleri önerilmektedir.

\section{Kaynakça}

Akmut, Ö. (1989). Sermaye Piyasası Analizleri ve Portföy Yönetimi. Ankara.

Aksoy, E. (2018). Bitcoin - Paradan Sonraki En Büyük İcat - Blockchain Teknolojisi ve Altcoin'ler. İstanbul: Abaküs.

Andrianto, Y., \& Diputra, Y. (2017). The Effect of Cryptocurrency on Investment Portfolio Effectiveness. Journal of Finance and Accounting, 5(6), 229-238.

Ankenbrand, T., \& Bieri, D. (2018). Assessment of cryptocurrencies as an asset class by their Investment. Management and Financial Innovations, 15(3), 169-181.

Ayan, T., \& Akay, A. (2013). Tahmine Dayalı Portföy Optimizasyonu: Modern Portföy Teorisinde Risk ve Beklenen Getiri Kavramlarına Alternatif Bir Yaklaşım. Dumlupınar Üniversitesi Sosyal Bilimler Dergisi, EYİ 2013 Özel Sayısı.

Basel Committee on Banking Supervision. (2003). Risk Management Principles for Electronic Banking. Basel. Ekim 9, 2020 tarihinde https://www.bis.org/publ/bcbs35.pdf adresinden alınd.

Berk, N. (2000). Finansal Yönetim. İstanbul: Türkmen Kitabevi.

Bernstein, P. L. (2008). Tanrılara karşı riskin olağanüstü tarihi. İstanbul: Scala Yayıncılık.

Bilir, H., \& Çay, Ş. (2016). Elektronik Para ve Finansal Piyasalar Arasındaki İlişki. Niğge Üniversitesi İktisadi ve İdari Bilimler Fakültesi Dergisi, 21-31.

BIS CPMI. (2015). Bank of International Settlements. BIS: https://www.bis.org Lcpmi/publ/d137.pdf adresinden alınd1

Bocconi Students Investment Club. (2017, 5 7). A Markowitz Walk Down Crypto-land: Modern Assets for Modern Portfolios. bsic.it: $\underline{\text { bsic.it }}$ adresinden alınd 1

Brauneis, A., \& Mestel, R. (2019). Cryptocurrency-portfolios in a mean-variance framework. Finance Research Letters, 28, 259-264. 
Buterin, V. (2013). Ethereum: A next-generation smart contract and decentralizedapplication platform. https://ethereum.org/en/whitepaper/ adresinden alınd1

Can, V. (2007). Luca Pacioli Muhasebenin Babası mıdır? Akademik Bakış, 12.

Ceylan, A., \& Korkmaz, T. (1998). Borsada Uygulamalı Portföy Yönetimi (3. b.). Bursa: Ekin Kitabevi.

Charnes, A., Cooper, W. W., \& Ijiri, Y. (1963). Breakeven Budgeting and Programming to Goals. Journal of Accounting Research, 16-43.

Cooper, R. N., Dornbusch, R., \& Hall, R. E. (1982). The Gold Standard: Historical Facts and Future Prospects. Brookings Papers on Economic Activity, 1-56.

Corbet, S., Lucey, B., Andrew, U., \& Yarovaya, L. (2019). Cryptocurrencies as a financial asset: A systematic analysis. International Review of Financial Analysis, 62, 182-199.

Ćosić, K., \& Časni, A. Č. (2019). The impact of cryptocurrency on the efficient frontier of emerging markets. Croatian Review of Economic, Business and Social Statistics, 5(2), 64-75.

Davies, G. (2002). A History of Money: From Ancient Times to Present day. Cardiff: University of Wales Press.

Dhillon, V., Metcalf, D., \& Hooper, M. (2017). Blockchain Enabled Applications: Understand the Blockchain Ecosystem and How to Make it Work for You. Florida, USA: Github Apress. doi:10.1007/978-1-4842-3081-7

Ebrey, P. B. (1999). The Cambridge Illustrated History of China. Cambridge: Cambridge University Press.

Fama, E. F. (1972). Components of Investment Performance. Journal of Finance, 27(3), 551-567.

Ferguson, N. (2011). Paranın Yükselişi - Dünyanın Finansal Tarihi. (B. Pala, Çev.) İstanbul: Yapı Kredi Yayınları.

Fernández, A., \& Gómez, S. (2007). Portfolio Selection Using Neural Networks. Computers E Operations Research, 34, 1177-1191.

Franco, P. (2014). Understanding Bitcoin: Cryptography, Engineering and Economics. John Wiley \& Sons.

Géhin, W. (2004). A Survey of the Literature on Hedge Fund Performance. Nice: EDHEC Business School - EDHEC Risk and Asset Management Research Centre.

Graeber, D. (2015). Borç: İlk 5000 Yıl. İstanbul: Everest Yayınları.

Gül, Y. (2020). Kripto Paralar ve Portföy Çeşitlendirmesi. Dumlupınar Üniversitesi Sosyal Bilimler Dergisi(65), 125-141.

Hazewinkel, R. (2017). Bitcoin: a diversifier, hedge or safe haven. Tilburg University.

Hecht, P. (2014, Kasim). How to Evaluate Hedge Funds or Any New Investment: Alphas, Sharpe Ratios and the Underutilized -but Most Important- Appraisal Ratio. Aralık 12, 2019 tarihinde Evanston Capital Management: https://www.evanstoncap.com/docs/news-andresearch/ecm-research-appraisal-ratio.pdf adresinden alındı 
Hileman, G., \& Rauchs, M. (2017). Global Cryptocurrency Benchmarking Study. Cambridge Center for Alternative Finance. https://econpapers.repec.org/RePEc:jbs:altfin:201704-gcbs adresinden alınd 1

Jacobs, B., Levy, K., \& Markowitz, H. (2005). Portfolio Optimization With Factors, Scenarios, and Realistic Short Positions. Operations Research, 53(4), 586-599.

Jensen, M. C. (1968). The Performance of Mutual Funds in the Period 1945-1964. The Journal of Finance, 23(2), 389-416.

Kajtazi, A., \& Moro, A. (2019). The role of bitcoin in well diversified portfolios: A comparative global study. International Review of Financial Analysis, 61, 143-157.

Kapusuzoğlu, A., \& İbicioğlu, M. (2013, Nisan). Portföy Çeşitlemesi: İMKB'de Sektörel Endeksler Üzerine Bir Analiz. Muhasebe ve Finansman Dergisi, 119-138.

Kardiyen, F. (2008). Portföy Optimizasyonunda Ortalama Mutlak Sapma Modeli ve Markowitz Modelinin Kullanımı ve İMKB Verilerine Uygulanması. Süleyman Demirel Üniversitesi İ̈BF Dergisi, 13(2), 335-350.

Keçeci, N. F. (2015). İkinci Derece Stokastik Baskınlık Kriteri ile Borsa İstanbul'da Etkinlik Analizi. Journal of Economics, Finance and Accounting, 2(3).

Keskintürk, T., Demirci, E., \& Tolun, S. (2010). İyi Çeşitlendirilmiş Portföy Büyüklügünün Genetik Algoritma Tekniği Kullanılarak İncelenmesi. Sosyal Bilimler Dergisi, 0(2).

Klabbers, S. (2017). Bitcoin as an investment asset: The added value of bitcoin in a global market portfolio. Nijmegen: Radboud Universiteit.

Korkmaz, T., Aydın, N., \& Sayılgan, G. (2013). Portföy Yönetimi. (M. Başar, Dü.) Eskişehir: T.C. Anadolu Üniversitesi Açıköğretim Fakültesi.

Küçükbay, F., \& Araz, C. (2016). Portfolio Selection Problem: A Comparison of Fuzzy Goal Programming and Linear Physical Programming. An International Journal of Optimization and Control: Theories E Applications, 6(2), 121-128. doi:DOI: 10.11121/ijocta.01.2016.00284

Küçükkocaoğlu, G. (2002). Optimal Portföyün Seçimi ve İMKB Ulusal-30 Endeksi Üzerine Bir Uygulama. Active Bankactlk ve Finans Dergisi, 74-91.

Law, J. (1705). Money and Trade Considered With a Proposal for Supplying the Nation with Money. Edinburgh: Andrew Anderson.

Liow, K. H. (1997). The Historical Performance of Singapore Property Stocks. Journal of Property Finance, 111-125.

Liu, W. (2018). Portfolio diversification across cryptocurrencies. Finance Research Letters, 29, 200-205.

Lloyd, S. (1997). Türkiye'nin Tarihi: Bir Gezginin gözüyle Anadolu Uygarlıkları. (E. Varinlioğlu, Çev.) Ankara: Tübitak Yayınları.

Maillard, D. (2012, Şubat 2). A User's Guide to the Cornish Fisher Expansion. SSRN: https://papers.ssrn.com/sol3/papers.cfm?abstract id=1997178 adresinden alındı

Markowitz, H. (1952, Mart). Portfolio Selection. The Journal of Finance, 7(1), 77-91. 
Martens de Wilmars, A., \& Vondeling, W. (2019). Bitcoin as a financial asset: Impact of Bitcoin on a well-diversified European portfolio. Universite catholique de Louvain, Louvain School of Management. http://hdl.handle.net/2078.1/thesis:15145 adresinden alınd1

Modigliani, F., \& Modigliani, L. (1997). Risk Adjusted Performance. Journal of Portfolio Management, 23, 45-54.

Mumcu, H. D. (2007). Uluslararası Para Sistemi, Avrupa'nın Parasal Entegrasyonu ve Oca Teorisi. İstanbul: Doktora Tezi.

Nam, Y. (2017). A New Opportunity of Bitcoin for Improving Portfolio Efficiency in Japan. Ritsumeikan Asia Pacific University.

Örten, R., Kurt, G., \& Torun, S. (2011). Muhasebede Çift Taraflı Kayıtlama ve Kitab-Us Siyakat. Muhasebe ve Finans Tarihi Araştırmaları Dergisi(1), 34-69.

Platanakis, E., \& Urquhart, A. (2019). Portfolio management with cryptocurrencies: The role of estimation risk. Economics Letters, 177, 76-80.

Platanakis, E., Sutcliffe, C., \& Urquhart, A. (2018). Optimal vs naïve diversification in cryptocurrencies. Economics Letters, 171, 93-96.

Prableen, B. (2019 May1s 07). Bitcoin May Be a Portfolio Diversifier but There Are Still Risks. The Street: https://www.thestreet.com/story/13877214/1/btcon-may-be-a-portfolo-dversfer-butthere-are-stll-rsks.html adresinden alınd1

Quesnelle, J. (2018). An Analysis of Anonymity in the Zcash Cryptocurrency. Master's Thesis. University of Michigan-Dearborn.

Ramage, A., \& Craddock, P. (2000). King Croesus' gold: excavations at Sardis and the history of gold refining. Cambridge: Harvard University Art Museums.

Reilly, F. K., \& Brown, K. C. (2011). Investment Analysis and Portfolio Management. Cengage Learning.

Resmi Gazete (6493 sayılı Kanun 27.06.2013 tarihli, 28690 sayılı Resmi Gazete 06 20, 2013).

Ripple. (2016). Whitepaper, https://ripple.com/files/xrp cost model paper.pdf. Ripple: https://ripple.com/files/xrp cost model paper.pdf adresinden alındı

Ryan, J. (2014). Historical Note: Did Double-Entry Bookkeeping Contribute to Economic Development,Specifically the Introduction of Capitalism? Australasian Accounting Business E Finance Journal, 8(3), 85-97.

Saksonova, S., \& Kuzmina-Merlino, I. (2019). Cryptocurrency as an Investment Instrument in a Modern Financial Market. St Petersburg University Journal of Economic Studies, 35(2), 269282.

Samarakoon, L. P., \& Hasan, T. (2006). Portfolio Performance Evaluation. C.-F. Lee içinde, The Encyclopedia of Finance (s. 617-622). Springer.

Scholz, H., \& Wilkens, M. (2005). A Jigsaw Puzzle of Basic Risk Adjusted Performance Measures. The Journal of Performance Measurement, 57-64.

Sharma, M. (2005). Searching for the Perfect Risk-Adjusted Performance Measure. Aralık 18, 2019 tarihinde QuantZ Capital Management LLC: http://www.quantzcap.com/RAPM\%20by\%20Sharma.pdf adresinden alınd 1 
Sharpe, W. F. (1994). The Sharpe Ratio. The Journal of Portfolio Management, 21(1), 49-58.

Smith, L. M. (2018). Luca Pacioli: The Father of Accounting. Texas: SSRN. https://papers.ssrn.com/sol3/papers.cfm?abstract id=2320658 adresinden alınd 1

Sortino, F., \& Price, L. (1994). Performance Measurement in a Downside Risk Framework. Journal of Investing, 3, 59-65.

Tarlan, S. (1986). Tarihte Bankacılık. Ankara: Ankara: Maliye Bakanlığı, Araştırma, Planlama ve Koordinasyon Kurulu Yayını.

Teker, S., Karakurum, E., \& Tav, O. (2008). Yatırım Fonlarının Risk Odaklı Performans Değerlemesi. Doğuş Üniversitesi Dergisi, 9(1), 89-105.

Tezer, Ö., \& Çolak, Ö. F. (1999). Finansal Sistem ve Bankalar. Ankara: Nobel Yayın Dağıtım.

Treynor, J. L. (1965). How to Rate Management of Investment Funds. Harvard Business Review, 43(1), 63-75.

Trimborn, S., Li, M., \& Hardle, W. (2017). Investing with cryptocurrencies - A liquidity constrained investment approach. Collaborative Research Center 649: Economic Risk. Berlin: Humboldt University.

Tuna, G. (2011, Ocak). Portföy Seçimi İçin Kovaryans Matrisi Tahmini: IMKB'de Minimum Varyanslı Portföy Uygulaması. Sakarya Üniversitesi Sosyal Bilimler Enstitüsü. Doktora Tezi.

UK Legislation. (2020). The E-Money Regulations. Ekim 9, 2020 tarihinde https://www.legislation.gov.uk/uksi/2011/99/regulation/2/made adresinden alınd1

Usta, A., \& Doğantekin, S. (2018). Blockchain 101. Bankalararası Kart Merkezi.

Usta, Ö., \& Demireli, E. (2012). Risk bileşenleri analizi: IMKB'de bir uygulama. Uluslararası Yönetim İktisat ve İşletme Dergisi, 25-36.

Yakupoğlu, C. (2016). A Comparative Study of Bitcoin and Alternative Cryptocurrencies. Ankara: Yıldırım Beyazıt Üniversitesi Fen Bilimleri Enstitüsü, Yüksek Lisans Tezi.

Yücel, Ö. (2016). BİST Endekslerinin Risk Temelli Performans Karşılaştırması. İşletme ve İktisat Çalışmaları Dergisi, 4(4), 151-164. 